\title{
The Most Esteemed Act of My Life: Family, Property, Will, and Trust in the Antebellum South
}

\author{
Alfred L. Brophy \\ University of Alabama - School of Law, abrophy@law.ua.edu \\ Stephen Duane Davis II \\ Government of the United States of America - Alabama, Northern District, stephen.davis@law.ua.edu
}

Follow this and additional works at: https://scholarship.law.ua.edu/fac_working_papers

\section{Recommended Citation}

Alfred L. Brophy \& Stephen D. Davis II, The Most Esteemed Act of My Life: Family, Property, Will, and Trust in the Antebellum South, (2009).

Available at: https://scholarship.law.ua.edu/fac_working_papers/41

This Working Paper is brought to you for free and open access by the Faculty Scholarship at Alabama Law Scholarly Commons. It has been accepted for inclusion in Working Papers by an authorized administrator of Alabama Law Scholarly Commons. 
"The most esteemed act of my life":

Family, Property, Will, and Trust in the Antebellum South

\author{
Stephen Duane Davis II $^{1}$ and Alfred L. Brophy ${ }^{2}$
}
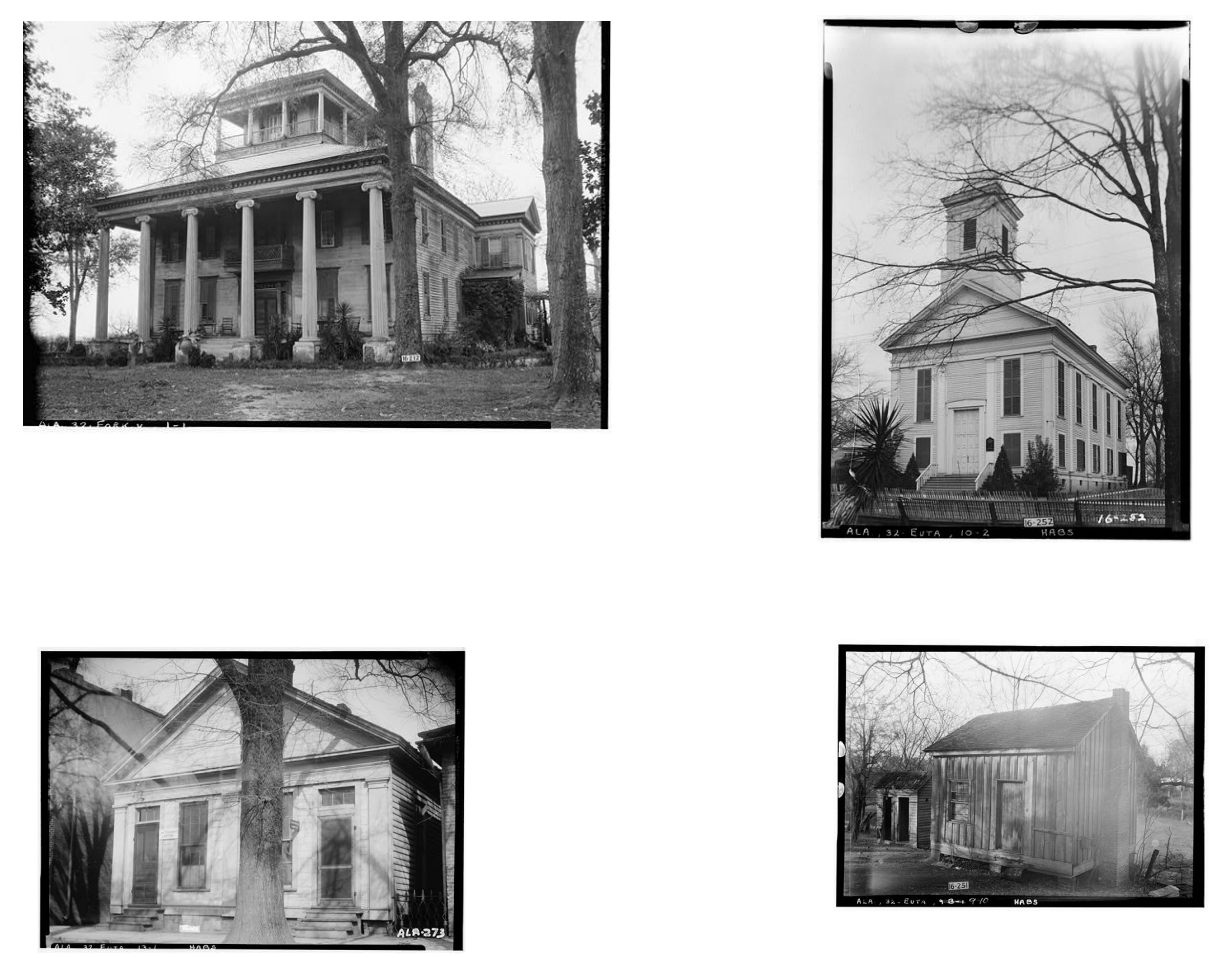

Photographs, from the Library of Congress' WPA's Historic Buildings Survey are (clockwise from upper left), Rosemont Plantation, Greene County, Alabama; Presbyterian Church, Eutaw, Alabama; Slave Quarters for Smith House, Eutaw, Alabama; and Law Office, Eutaw, Alabama.

${ }^{1}$ Law Clerk to Hon. Inge P. Johnson, United States District Court, Northern District of Alabama.

${ }^{2}$ Reef C. Ivey II Professor of Law, University of North Carolina. abrophy@email.unc.edu 


\title{
"The most esteemed act of my life": Family, Property, Will, and Trust in the Antebellum South*
}

\begin{abstract}
"The Most Esteemed Act of My Life" combines an empirical study of probate in Greene County, Alabama, one of the wealthiest counties in the United States in the years leading into Civil War, with a qualitative examination of property doctrine and ideology at that time. The data address three key themes in recent trusts and estates literature. First, what testators did with their extraordinary wealth; in particular, how they worked to maintain property within their families--and especially how male testators were suspicious of loss of their family's wealth through their daughters' marriages. Second, the testators used sophisticated trust mechanisms for both managing property and keeping it within their families. In the antebellum era, Americans celebrated the ways they harnessed technologies, from the steam engine to the telegraph and printing press, to create wealth and improve society. This study reveals that trusts should be added to that list of technologies that assisted in the creation and management of wealth. Finally, the data reveal the salience of enslaved human property--often managed through trusts after their owners died and also frequently divided between family members--to the maintenance of family wealth.
\end{abstract}

While some in the United States at the time--including some jurists, as well as politicians and novelists--questioned the desirability to our country of inheritance, the Greene County data show an extraordinary devotion to maintenance of family wealth. The findings in "The Most Esteemed Act of My Life" invite further study in other places in the South, as well as in the North, to test the extent to which the existence of wealth (particularly a wealth based on human property) led to different patterns of bequest from those seen among some of our nation's wealthiest individuals at critical period of American history.

* The authors would like to thank Guy Hubbs and Lawrence Kohl for their comments on this paper.

All of the tables referenced here are available on the internet at: http://blurblawg.typepad.com/files/greenecountytables2-1.doc 
There is a county in the heart of Alabama, where the cotton that fueled our nation's economic development-and the world's industry and trade in cotton cloth-was grown. In fact, cotton still is grown there, though that industry has lost its prime place in our country's economy. The county was carved out of the wilderness in the $1810 \mathrm{~s}$. At the time of the Civil War, more than 140 people in that county each owned at least 100 people-more than all but three other counties in Alabama. ${ }^{3}$ None of those owners are still alive and neither are any of the people they owned, those who labored in fields of Greene County to create such wealth. But some of the descendants of those people still live there and some of the houses they lived in are still there. They were spared the torch during the Civil War because Greene County is so much at the heart of the south that the war was just about over by the time United States soldiers reached it in 1865. They hurried past it toward Selma and one of the last battles of the Civil War. So, too, some of the records of that wealth were spared. Thus, in the courthouse at Eutaw, along the town square where business has been conducted for nearly two centuries, lie the records of the transmission of wealth at death. This is the story of some of those records, the stories they record, and what those stories in turn tell us about the role of families and transmission of wealth in the old South. ${ }^{4}$

In the years leading into Civil War, many in the United States spoke about the virtues of property. The power of property brought civilization and commerce in its wake. ${ }^{5}$ But at the same time, they expressed skepticism of the concentration of wealth, particularly of corporations and of trusts. ${ }^{6}$ The Jacksonian era included conflict over visions of property and corporations

\section{J. Mills Thornton III, Politics and Power in a Slave Society 345 (1978).}

${ }^{4}$ With thanks to Anthony Wallace's Rockdale 3 (1972) for a model for the beginning paragraph.

5 See, e.g., Atkinson v. Ball, 26 Va. (5 Rand.) 446, *4 (1827) ("A sacred regard to the rights of property, is the foundation of all law and civilization; and the smallest scintilla of right ought not to be invaded.") The recognition of property rights was also a sign of civilization. See, e.g., Trustees of McIntire Poor School v. Zanesville Canal \& Mfg. Co., 9 Ohio 203, 286 (1838) ("one of the earliest elements of every social community, thrown upon its lawgivers at the dawn of its civilization, is adequate protection to its property and institutions, which subserve public uses, or are devoted to its elevation, or consecrated to its religious culture and its sepultures...."). The free alienability of property was another sign of civilization. Carder v. McDermett 12 Tex. 546, *2 (1854) ("wherever restrictions of any rigor, from considerations of policy, well or ill-founded, have been imposed on alienation, history reveals the fact of incessant struggles against the thraldom. And the success of these efforts appears to have been commensurate with the advancement of civilization, and of more just and enlightened views relative to the true uses of property as subservient to the multiplied wants of refined social life.").

6 Trs. of Davidson Coll., 56 N.C. (3 Jones) at 266 (expressing concern in English law about concentration of wealth in hands of religious institutions and the declining availability of that land for productive purposes). See also Gallego's Exrs' v. Virginia, 30 Va. (3 Leigh) 450, 478 (1832) (resting law's suspicion of charitable corporations on the fear of accumulation of 
and inherited wealth. Whigs like Chancellor James Kent and Joseph Story worried when Democrats like Chief Justice Roger B. Taney narrowly interpreted corporations' rights under public charters. ${ }^{7}$ Those conflicts appeared throughout the state courts as well. ${ }^{8}$ Moreover, it was a time of transition in wealth transmission for three reasons. First, some states had only recently departed from a regime of leaving property to the eldest male child and permitting the entail of property; second, the Married Women's Property Acts beginning in the 1830s allowed women substantially increased power over the control and use of property; ${ }^{9}$ third, the increasing use of personal rather than real property, such as stock in corporations and bank notes, allowed greater flexibility in the distribution of property to family members. ${ }^{10}$

This study of testamentary devises in a black belt county in Alabama (the name given to the counties where the black, rich soil supported the huge plantations for which the Old South is remembered) allows a partial measurement of how wealth was preserved within families and how the process of transmission worked across generations. It is motivated by demographic questions about the probate process: what proportions of men and women used it? What was their status within the family? It is also motivated by questions about the use those people made of the probate process. In what circumstances do people leave property to their spouses, children, siblings, or charities? What kind of property do they leave and when did they employ trusts? How were wills and trusts used to keep property within families? This is an attempt to capture a picture of the transmission of wealth in one of the wealthiest counties in the United States in the years leading into Civil War. There are, moreover, important questions about the transmission of wealth in human beings.

Others have studied such questions for colonial era in Massachusetts, New Jersey, and

property).

7 See, e.g., Charles River Bridge v. Warren Bridge Co., 36 U.S. 420 (1837); James Kent, Supreme Court of the United States, 2 N.Y. REv. 372, 372 (1838).

8 See, e.g., Shorter v. Smith, 9 Ga. 517 (1851) (narrowly construing a public charter to a bridge company); McLeod v. Savannah, Albany and Gulf R. Co., 25 Ga. 445 (1858) (narrowly constructing charter to a bridge company against a competing bridge-builder).

9 See Linda Kerber, Women of the Republic: Intellect and Ideology in Revolutionary AMERICA (1980) (finding restriction in women's legal rights in early nineteenth century); MARY Beth Norton, Founding Mothers \& Fathers: Gendered Power and the Forming of AMERICAN SOCIETy (1997) (finding restrictions on women's legal rights around the American Revolution). Catherine Clinton, The Plantation Mistress (1984); Marli F. Weiner, Mistresses and Slaves: Plantation Women in South Carolina, 1830-80 (1997).

${ }^{10}$ See Carole Shammas, Marylynn Salmon \& Michael Dahlin, Inheritance in America: From Colonial Times to the Present 63-102 (1987) (discussing changes in inheritance practices, particularly in the nineteenth century). 
Pennsylvania ${ }^{11}$ and for certain areas of the South, ${ }^{12}$ especially for African Americans in the South in the years after the Civil War. ${ }^{13}$ However, Alabama's planters have escaped that same level of scrutiny. In looking to Greene County in the 1830s and 1840s, we hope to add additional light to the interaction of legal process and planter's ideas and behavior and to spur further investigation of such questions by suggesting ways that legal doctrine and local records can be used in conjunction to piece together a comprehensive picture of the probate process in the old South. ${ }^{14}$ This article, thus, seeks to join social history of the probate process with its legal history and, thus, illuminate the ways that the legal technology of the will was responding

${ }^{11}$ See, e.g., Philip Greven, Four Generations: Population, Land, and Family in Colonial Andover, Massachusetts (1970); Barry Levy, Quakers and the American Family: British Settlement in the Delaware Valley (1988); Lawrence M. Friedman, Patterns of Testation in the Nineteenth Century: A Study of Essex County (NJ) Wills, 8 AM. J. L. Hist. 34 (1964); James W. Deen, Patterns of Testation: Four Tidewater Counties in the Colonial Era, 16 AM. J.L. Hist. 154 (1972). Other studies that have examined patterns of testation, either as a historical or contemporary phenomena include Allison Dunham, The Method, Process and Frequency of Wealth Transmission at Death, 30 U. CHI. L. REV. 241, 241 (1962-1963); Lawrence M. Friedman, The Law of the Living, The Law of the Dead: Property, Succession, and Society, 1966 Wis. L. REV. 340, 354-55; Olin L. Browder Jr., Recent Patterns of Testate Succession in the United States and England, 67 Mich. L. Rev. 1303, 1303 (1968-1969); Jeffrey A. Schoenblum, Will Contests - An Empirical Study, 22 ReAl Prop. Prob. \& Tr. J. 607, 607 (1987).

12 See Suzanne Lebsock, The Free Women of Petersburg: Status and Culture in a SOUTHERn TOWn, 1784-1860 54-86, 130 (1984) (detailing patterns of bequests and gifts and reporting rates of intestacy for women in antebellum Petersburg, Virginia); HENRY WIENCEK, The Hairstons: An American Family in Black And White 78, 89 (1999) (detailing use of trusts in maintaining property within one of the most wealthy families in the antebellum South, as well as will contests and related conflicts).

13 See Adrienne D. Davis, The Private Law of Race and Sex: An Antebellum Perspective, 51 Stanford Law ReVIEW 221-288 (1999). Dylan Penningroth explores African American conceptions of families in Claims of Kinfolk: African American Property and Community in the Nineteenth-Century South (2003). This study also draws upon recent legal histories of the old South that have turned to local court records to answer questions about how the institution of slavery function and how court records illustrate the concerns of slaveholders. See, e.g., ArIELA Gross, Double Character: Slavery and Mastery in the Antebellum Southern Courtroom (2000); Laura F. Edwards, The People and Their Peace: Legal Culture and the Transformation of Inequality int eh Post-Revolutionary South (2009).

14 See William K. Scarborough, Masters of the Big House: Elite Slaveholders of the Mid-Nineteenth Century (2003). 
to testators' desire to keep property within the family and carry out their wishes. ${ }^{15}$

This study, then, seeks to answer several sets of related questions. First, basic ones about how wills and trusts were used to transfer wealth between generations and preserve wealth within families. That data in turn reveals the centrality of the family-but also divisions between testators about the appropriate distribution of property within their families. It exposes the antebellum period as a time of extraordinary wealth, as well as questions about the ways to distribute that wealth. How was property distributed? How did trusts function to maintain control and assist family members? How to treat children, spouses, siblings, and enslaved people who are owned. It reveals the ways that the legal system was used to achieve the desires of those with property, as well as what those desires were. This is particularly important because in the years leading into Civil War, our country was in transition towards a robust market economy.

\section{Inheritance in the Antebellum Mind}

Wills and inherited wealth loomed large in the minds of antebellum Americans. Those ideas appeared in the fictional literature that revolved around conflicts over wills and the fear that Americans felt about losing their inheritance or never receiving one in the first place. They also appeared in the debates Americans had about inheritance and about concentrations of wealth, like the Anti-Rent movement in upstate New York and in the conflict over how courts should treat charitable trusts. Judges' conflicts about the treatment of trusts to free slaves revealed particularly strong disjunctures in thought about property, inheritance, and the state's interest in limiting the pernicious use of property.

\section{A. Fictional Literature}

Fictional literature from the leaders of the American Renaissance like Edgar Allen Poe and Nathaniel Hawthorne to obscure figures like Nathaniel Beverly Tucker and Carolyn Hentz frequently dealt with the conflicts engendered by wills. Catharine Marie Sedgwick's 1830 novel Clarence, for instance, revolved around an elderly man's will that left property to his long-lost son. The son's family spent so much time fighting for the inheritance that one of the their children died from neglect. ${ }^{16}$

Edgar Allen Poe's short story “The Domain of Arnheim," tells of a beautiful garden, in an otherwise barren land. ${ }^{17}$ The domain was built by Seabright Ellison using a fortune (of 450 million dollars) left to him by a remote ancestor, who had devised his fortune to his nearest living heir 100 years after his death. Poe noted the efforts that had been made to defeat the devise (and though they were ineffective, the state legislature prevented similar devises by

\footnotetext{
15 See Lawrence Friedman, Dead Hands: A Social History of Wills (2009).

16 Catharine Marie Sedgwick, Clarence (New York, 1830).

17 See Domain of Arnheim, 1 The Works Of The Late Edgar Allan Poe 388 (New York, Redfield 1857); The Landscape Garden, LADY's COMPANION (October 1842).
} 
statute). ${ }^{18}$ No one could even begin to conceive of how to spend that fortune, which would generate more than a million dollars a month in income. So Ellison set about "solving what has always seemed to [Poe] an enigma":

that no such combination of scenery exists in nature as the painter of genius may produce. No such paradises are to be found in reality as have glowed on the canvas of Claude. In the most enchanting of natural landscapes there will always be found a defect or an excess -- many excesses and defects. While the component parts may defy, individually, the highest skill of the artist, the arrangement of these parts will always be susceptible of improvement. In short, no position can be attained on the wide surface of the natural earth, from which an artistical eye, looking steadily, will not find matter of offence in what is termed the 'composition' of the landscape. ${ }^{19}$

The domain was made to look like nature, but it was artificial. It shows the ways that humans might try to create the sublime, in landscape, as in literature.

What is perhaps most exciting about the "Domain of Arnheim" is that is it based on the 1799 English case of Thellusson v. Woodford. The testator, Peter Thellusson, left a fortune of $£ 800,000$ to the eldest male lineal descendant, who was alive immediately after the death of all the testator's issue living at the time of the testator's death. In essence, the testator wanted to disinherit all of his living relatives and leave the money to a remote descendant-a person he had never met and could not meet. Moreover, the money was to accumulate while it was waiting for the remote descendant to become eligible to take the estate. That led to Parliament's passage in 1800 of the Thelluson Act, which limited the accumulations that were permissible. ${ }^{20}$ Thus, Poe's short story was motivated by a case that itself was important part of the emerging law that limited inherited wealth. A short story about the ways that humans tried to improve upon nature was motivated by a legal controversy that itself was about the struggle to limit inherited wealth. ${ }^{21}$

And in Tuscaloosa, there was Carolyn Hentz, who ran the female seminary in town. Her short story in Magnolia Leaves is about the Harrington family, who lost their inheritance. The family was left only the remnants of their estate, which had a huge elm tree in front of it. When the estate, even, was purchased by a newly wealthy merchant, he cut it down, as a sign of his dominion over the land. Yet, years later, through hard work, the son of the family became a successful lawyer and was elected to Congress. He then married the daughter of the merchant and, in that way, reclaimed some of his family's estate. It was a moment of reclamation through

18 Domain of Arnheim, supra note 17, at 389-90.

${ }^{19} I d$. at 392-93.

${ }^{20}$ Robert Sitkoff, The Lurking Rule Against Accumulations of Income, 100 Nw. U. L. REV. 501 (2006).

${ }^{21}$ For more on Thellusson v. Woodford, 32 Eng. Rep. 1030 (1805), see Gregory Alexander, Commodity and Property: Competing Visions of Property in American Legal Though, 17761970 120-21 (1997). 
work and through family. ${ }^{22}$ As Americans struggled in the early national period with the uncertain economy and carving out an existence from the wilderness, they wondered what their inheritance might be. What was left them as a people by their ancestors and what was left them as individuals by their parents and grandparents?

Such a theme, of maintaining property within the family, appeared in post-bellum literature as well. In Henry James' Washington Square a father desires to protect his family property from a penniless suitor, in part through a plan to leave her without an inheritance. And, in fact, he does not leave her much money, as a way of warding off the suitor; the daughter never marries. But none of the wills in Greene County illustrate the short-sightedness of the father in Washington Square, Dr. Austin Sloper. Whether the families were prone to such self-destructive behavior that appeared in literature is a subject worth attention.

Some of the inheritance was left to the nation as a whole. Justice Joseph Story, speaking to the Harvard Phi Beta Kappa Society in 1826 spoke of the inheritance offered to all Americans:

What shall we say of this nation, which has in fifty years quadrupled its population, and spread itself from the Atlantic to the Rocky Mountains, not by the desolations of successful war, but by the triumphant march of industry and enterprise? ... She has risen, as it were, from the depths of the ocean, where she had been buried for ages. Her shores no longer murmur with the hoarse surges of her unnavigated waters, or echo the jealous footsteps of her armed oppressors. Her forests and her table lands, her mountains and her vallies, gladden with the voices of the free. She welcomes to her ports the whitening sails of commerce. She feels, that the treasures of her mines, the broad expanse of her rivers, the beauty of her lakes, the grandeur of her scenery, the products of her fertile and inexhaustible soil, are no longer the close domain of a distant sovereign, but the free inheritance of her own children. ${ }^{23}$

More commonly, antebellum Americans thought of inheritances that descended within

22 Carolyn Hentz, Magnolia Leaves No. IX, in Wild Jack; Or, The Stolen Child and Other Stories 236, 237 (Philadelphia, A. Hart, 1854) ("We have a property in those trees-they are a part of our inheritance-and we would mourn for the stroke that defaced or maimed them, as a personal injury to ourselves. We feel enriched every time we gaze upon them, and pity the poor being who can pass them without a glowing tribute of praise and admiration.").

23 Joseph Story, Discourse at Cambridge, Before the Phi Beta Kappa Society of Harvard University, on the Thirty- First of August 1826 (Boston: Hilliard, Gray, Little, and Wilkins, 1826), in 2 American Eloquence: a Collection of Speeches and Addresses, By the Most Eminent of Authors 424, 434 (D. Appleton, New York, 1857). See also id. at 425 ("We ask admission into the temple of fame, as joint heirs of the inheritance, capable in the manhood of our strength of maintaining our title."). On public inheritance more generally, see Joyce Appleby, Inheriting the Revolution: The First Generation of Americans (2000). Henry Hallam wrote of the increasing "pride ... in the name of Englishmen, and in the inheritance of traditionary English privileges" after the loss of Normandy. 3 Henry Hallam, History of Europe During the Middle Ages 169 (Raymond Marsh ed., Colonial Press ed. 1900). 
families. ${ }^{24}$ Nathaniel Beverly Tucker's 1836 novel George Balcombe revolved around a lost will and the efforts to reclaim that will and the inheritance that was left to the young Balcombe. It was a case where the reclamation of the family's inheritance would permit them to lead a decent life. One metaphor for Americans of that era was that money rightly owed a family ought to be paid the family and it could spare the family. ${ }^{25}$

For many in antebellum America, inheritance was in tension with equality. It became a part a question of vested rights against labor. For whether one acquired money through work was in tension with those who inherited a fortune. And in other places that tension appeared again, including James Fenimore Cooper's trilogy on the New York anti-rent movement. Published in the 1840s, the trilogy-particularly Redskins, the culmination of the trilogy, focused on the conflict between inherited wealth and those more numerous crowds who would use legislation, court suits, and ultimately violence to take away the inheritance. ${ }^{26}$ In Redburn,

${ }^{24}$ On private inheritance, see Toby L. Ditz, Property and Kinship: Inheritance in Early Connecticut, 1750-1820 (1986); Toby L. Ditz, Ownership and Obligation: Inheritance and Patriarchal Households in Connecticut, 1750-1820, 47 WM \& MARY Q. 235-65 (April 1990); Deborah A. Rosen, Women and Property Across Colonial America: A Comparison of Legal Systems in New Mexico and New York, 60 WM. \& MARY. Q. 355-81 (2003); Karen Hyde Weissman, Property and Gender in the Inheritance Patterns of a Southern Appalachian Community: Boone County, West Virginia, 1865-1924, 30 J. FAmiLy Hist. 48 (2005). Studies for the colonial era reveal extensive participation by women in the economy; this study focuses on both attempts to limit the economic independence of women, as well as the subtle and complex ways that women with property also exercised control over that property-even after their death-to give their issue control over property. See, e.g., More Than Her "Thirds": Wives and Widows in Colonial Virginia; Kristi A. Rutz-Robbin, "Divers Debts": Women's Participation in the Local Economy, Albemarle, North Carolina, 1663-1729, 4 EARLy Am. Stud. 425-441 (2006); Joan R. Gunderson, Independence, Citizenship, and the American Revolution, 13 Signs 59-77 (1987); Joseph A. Rosenberg, Supplemental Needs Trusts for People with Disabilities: The Development of a Private Trust in the Public Interest, 10 B.U. PuB. L.J. 91, 104 (2000) (citing Peter Charles Hoffer, The Law's Conscience 251-52 (1990) (describing multiple ways that trusts were used in the nineteenth century)).

25 See Nathaniel Beverly Tucker, George Balcombe (New York, 1836). For a description of the novel, which focuses on inheritance, see [Edgar Allen Poe,] George Balcombe, $3 \mathrm{~S}$. LiTERARY MESSENGER 49, 58 (1837).

26 James Fenimore CoOper, The Redskins (1846).

A satirical response to Uncle Tom's Cabin, written to mock the proslavery responses, similarly invokes the imagery of inheritance:

Finally, and comprehensively, the fugitive law of 1850 is in very exact accordance with the constitution of the United States, as the objects of that constitution are set forth in its preamble. ... "To secure the blessings of liberty, to ourselves and to our posterity:" nothing will contribute more fully to this than the complete subjugation of the $n$ order that, by their labor and sweat, their owners may be at liberty to enjoy themselves as 
Herman Melville described the process of dividing tobacco among sailors as the fairest system that could be imagined. He then recommended it to those dividing an estate:

Their mode of dividing this tobacco was the rather curious one generally adopted by sailors, when the highest possible degree of impartiality is desirable. I will describe it, recommending its earnest consideration to all heirs, who may hereafter divide an inheritance ; for if they adopted this nautical method, that universally slanderous aphorism of Lavater could be forever rendered nugatory - "Expect not to understand any man till you have divided with him an inheritance." 27

Melville also used inheritance in the broader political sense in White Jacket:

[W]e Americans are the peculiar, chosen people — the Israel of our time; we bear the ark of the liberties of the world. Seventy years ago we escaped from thrall; and, besides our first birthright - embracing one continent of earth — God has given to us, for a future inheritance, the broad domains of the political pagans, that shall yet come and lie down under the shade of our ark, without bloody hands being lifted. God has predestinated. Mankind expects, great things from our race; and great things we feel in our souls. ${ }^{28}$

This was a picture that James Madison predicted around the framing of the Constitution, when he warned about the conflict between the factions of the property holders and the propertyless. ${ }^{29}$ The fictional literature cast light at oblique angles on Americans' ideas about the probate process.

\section{B. Political Thought on Inheritance}

Some of the leading changes in law at the time of the Revolution was the abolition of

much as they please; while, by the subjugation of all the slave posterity, the posterity of the owners may inherit the luxury and ease of their fathers. Nicholas Brimblecomb, Uncle Tom's Cabin in Ruins!: Triumphant Defence of Slavery! In a Series of Letters to Harriet Beecher Stowe 53 (Boston, Charles Waite 1853).

27 Herman Melville, Redburn: His First Voyage 340 (New York: Harper \& Brothers, $1850)$.

28 Herman Melville, White Jacket: Or, The World in a Man-of-War 144 (Boston, 1892).

29 Property, 29 Mar. 1792, James Madison Writings (Jack N. Rakove ed., Library Am. ed. 1989) ("Where an excess of power prevails, property of no sort is duly respected. No man is safe in his opinions, his person, his faculties, or his possessions. Where there is an excess of liberty, the effect is the same, tho' from an opposite cause."). 
entail and primogeniture for intestate estates. ${ }^{30}$ These changes, so seemingly small to use (particularly in light of the fact that they entail could be docked and primogeniture could be avoided by the use of a will), captured the attention of antebellum Americans. They believed It was the inheritance law that accounted for much of the United States' distinctive character. Daniel Webster's 1820 address at Plymouth provides one example. Through the elimination of the rule of primogeniture for intestate estates and the discouragement of entail, Webster saw our legal system as encouraging wide distribution of property:

The character of their political institutions was determined by the fundamental laws respecting property. The laws rendered estates divisible among sons and daughters. The right of primogeniture, at first limited and curtailed, was afterwards abolished. The property was all freehold. The entailment of estates, long trusts, and the other processes for fettering and tying up inheritances, were not applicable to the condition of society, and seldom made use of. On the contrary, alienation of the land was every way facilitated, even to the subjecting of it to every species of debt. The establishment of public registries, and the simplicity of our forms of conveyance, have greatly facilitated the change of real estate from one proprietor to another. The consequence of all these causes has been a great subdivision of the soil, and a great equality of condition; the true basis, most certainly, of a popular government. ${ }^{31}$

Webster saw in the United States' equitable division of property the keys to our country's stability and progress. "If the people," says Harrington, "hold three parts in four of the territory, it is plain there can neither be any single person nor nobility able to dispute the government with them; in this case, therefore, except force be interposed, they govern themselves." Webster saw these lessons confirmed in English history:

It has been estimated, if I mistake not, that about the time of Henry the Seventh four fifths of the land in England was holden by the great barons and ecclesiastics. The effects of a growing commerce soon afterwards began to break in on this state of things, and before the Revolution, in 1088, a vast change had been wrought. It may be thought

30 See John V. Orth, After the Revolution: "Reform" of the Law of Inheritance, 10 L. \& HisT. REV. 33, 40-42 (1992) (discussing fear of concentration of wealth in early National period in Virginia and North Carolina); Stanley N. Katz, Republicanism and the Law of Inheritance in the American Revolutionary Era, 76 MICH. L. REV. 1 (1977); Holly Brewer, Entailing Aristocracy in Colonial Virginia: "Ancient Feudal Restraints" and Revolutionary Reform, 54 WM. \& MARY Q. 307 (1997) (finding predominance of entail in colonial Virginia). Claire Priest attributes this to the rise in alienability-that people could sell (or mortgage) property not subject to entail and that creditors could put liens on entailed property. See Claire Priest, Creating an American Property Law: Alienability and Its Limits in American Law, 120 HARV. L. REV. 385 (2006).

31 Daniel Webster, First Settlement of New England: A Discourse Delivered at Plymouth, on the $22^{\text {nd }}$ of December, 1822, in The Great Speeches and Orations of Daniel Webster 25, 44 (Edwin Percy Whipple ed., 1914). 
probable, that, for the last half-century, the process of subdivision in England has been retarded, if not reversed; that the great weight of taxation has compelled many of the lesser freeholders to dispose of their estates, and to seek employment in the army and navy, in the professions of civil life, in commerce, or in the colonies. The effect of this on the British constitution cannot but be most unfavorable. A few large estates grow larger; but the number of those who have no estates also increases; and there may be danger, lest the inequality of property become so great, that those who possess it may be dispossessed by force; in other words, that the government may be overturned. ${ }^{32}$

Judges were increasingly accommodating of increases in concentration of wealth via trusts. As recently as 1820, Chief Justice Marshall struck down a bequest to the Philadelphia Baptist Association for the establishment of a seminary, on technical grounds that seemed to have their basis in fear the power of concentration of wealth in religious societies. But by 1844 in Vidal v. Girard's Executors, popularly known as the Girard College case, Justice Joseph Story upheld a trust in favor of a school for orphans, in the face of precedent that was skeptical of charitable devises. ${ }^{33}$ As personal property-particularly in the form of shares of corporations-grew, the use of trusts and the sophistication of trust law grew.

Indeed, there was frequent invocation of the language of inheritance when speaking of Americans' political rights. Virginia lawyer Jesse Harrison wrote in 1832 in the wake of debate in the Virginia legislature about what to do about slavery. Thought the proslavery side had prevailed, the antislavery Harrison was still struggling against growing proslavery sentiments. The young Harrison, educated at Hampden Sydney College and Harvard Law School, wanted to impress"the exceeding desirableness and the urgent necessity of doing something promptly." For if slavery was not curbed soon, future generations would have to deal with it. He looked forward to the time when the current generation thought it best to do something and when the current generation thought it their "duty to the posterity who are to inherit the 'fee simple' of Virginia" to do something to end slavery. ${ }^{34}$

Of course legal literature soundly supported the right of testators to dispose of their property. Nanthaniel Chipman's 1833 treatise, Principles of Government ${ }^{35}$ for instance, found the right of testation was a natural right.

\section{The Trust to Free the Enslaved}

${ }^{32}$ Id . at 44 . Supreme Court Joseph Story told a similar story in his 1826 address to the Harvard Phi Beta Kappa Society. See Story, supra note 23.

${ }^{33}$ Vidal v. Girard's Executors, 43 U. S. 127 (1844).

${ }^{34}$ See [Jesse Burton Harrison], The Slavery Question in Virginia, 12 Am. Q. Rev. 379, 382 (Dec. 1832) (reviewing The Speech of Thomas Marshall in the House of Delegates of Virginia, on the Abolition of SlaVery, Friday January 20, 1832).

35 Nathaniel Chipman, Principles of Government: A Treatise on Free Institutions (Burlington, 1833). 
For Southern states there was another, significant question about testamentary freedom: what to do with slave owners who wanted to free their slaves at death. In the years after the American Revolution, many slaveowners provided for freedom for their slaves via will. George Washington, for instance, provided that upon his wife's death that slaves he owned would be freed. The Revolutionary War hero Thaddeus Kosciuszko established a testamentary trust using money paid him by the Congress for his service during the Revolution (and named Thomas Jefferson trustee) to provide money for the emancipation of slaves. Although Jefferson refused to accept the trust and the case wen to the Supreme Court twice in the 1830 s. $^{36}$ Some of the early nation's most complex litigation surrounded testamentary trusts to free slaves. For example, the Virginia Court of Appeals confronted in Pleasants $v$. Pleasants an attempt by a Quaker testator to put the humans he owned into trust and then provide for their education.

By the early nineteenth century, legislatures in Southern states increasingly put restrictions on the ability of owners to emancipate their slaves. An 1803 Virginia statute prohibited the emancipation of slaves without the consent of the local court; afterwards, perhaps in part because of the law but also because of changing attitudes towards emancipation, the emancipations were infrequent. Similarly, Georgia statutes in 1801 and 1818 prohibited emancipation by will. ${ }^{37}$ Alabama and Mississippi had similar statutes. ${ }^{38}$ And while one Mississippi court in 1860 concluded that the "design" of such acts "was not to interfere, unnecessarily, with the great and sacred right of testamentary disposition," such acts had the effect of limiting rather dramatically the uses that owners might make of their property. ${ }^{9} 3$

Courts routinely upheld those restrictions on emancipation via will if the slaves were to be freed in the state. But there was a question about how broadly such statues should be interpreted. What if the will provided that slaves were to be taken outside of the state and emancipated. Not surprisingly, those who were outside of the state and thus beyond the reach of the court at the time of the probate of the will were routinely held freed. Justice Henry Lumpkin of the Georgia Supreme Court understood the folly of trying to come to a different result when he asked of the 1801 Georgia statute: "Did the Legislature of 1801 design to render themselves ridiculous, by the promulgation of a brutum fulmen, that slaves set free by their removal to a free State, should still be in a state of slavery?" ${ }^{40}$ Lumpkin wrote several of the leading opinions interpreting the power of testators to place slaves in trust, to be transported out of the state and emancipated in a free state or in Africa. In 1854 in Cleland v. Waters, for instance, he surveyed

${ }^{36}$ Armstrong v. Lear, 33 U.S. 52 (1834).

37 Act Prescribing the Mode of Manumitting Slaves In This State, 1801.

38 See Clement C. Clay, A Digest of the Laws of the State of Alabama 539-46 (Tuscaloosa, 1843).

${ }^{39}$ Garnett v. Cowles, 39 Miss. (10 George) 60 (1860) (denying effect to part of will that would have devised two slaves to the American Colonization Society, but probating the remainder).

40 Sanders v. Ward, 25 Ga. 109 (1858). 
the history of Georgia's attitudes towards emancipation. Beginning in 1816, the many approved transporting slaves to Liberia.. In 1820, the Governor ordered that slaves illegally imported into the state should be turned over to the American Colonization Society. In the early 1820s, Georgians-still, in Lumpkin's mind unaware of "the true character" of slavery-supported colonization and emancipation. When in 1825 Georgia's governor warned about the need to protect against abolitionists, the legislature did nothing. But because of the "blind zealots of the North," there was a "settled conviction that it was wisely ordained by a forecast high as heaven above man's, for the good of both races, and a calm and fixed determination to preserve and defend [slavery], at any and all hazards." ${ }^{41}$ But, despite continuing and building evidence of a legislature's concern about colonization, judicial decisions had steadily supported the transportation of slaves outside of the state for emancipation. Lumpkin did not want to interfere with that precedent. He faced the issue again when Cleland $v$. Waters was before the court a year later in 1855. And again Lumpkin upheld the devise, although this time the Georgia Supreme Court's growing proslavery sentiment appeared in a short dissent by Justice Henry Lewis Benning.

Lumpkin faced these questions later, as anti-emancipation sentiment continued to grow. In 1858 in Sanders $v$. Ward he upheld again a testamentary trust in which a testator placed slaves into trust and then instructed the trustees to transport the slaves to a free jurisdiction and emancipate them. Sanders particularly illuminating because Lumpkin upheld such a trust over a vigorous dissent; it is all the more interesting, because, though he upheld the trust, Lumpkin was strongly opposed to emancipation. Ward gives us a window into the nature of legal reasoning.

Lumpkin is clear that he opposes emancipation. He said he had "no partiality for foreign any more than domestic manumission. I believe that policy, as well as humanity for the negro, forbid both. Especially do I object to the colonization of our negroes upon our northwestern frontier. They facilitate the escape of our fugitive slaves. In case of civil war, they would become an element of strength to the enemy, as well as of annoyance to ourselves." Lumpkin even opposed emancipation after an owner's death by taking the slaves outside of the state. He noted that in the last session of the legislature a bill to prohibit foreign emancipation was introduced but failed to pass. While he would have voted for the bill, he wondered: "Is it for the Courts, then, to inaugurate this new policy, or to be forever importuned and harassed with this subject, at each change of incumbents upon this Bench? I trust the question will be considered as settled, until the Legislature see fit to intervene. Let that body speak, and no one will take more pleasure than myself in obeying their behest. Sworn as I am, not to make but to administer the law, I never can torture the law, as it now stands, to a purpose for which $I$ know it never was intended." 42

But Lumkpin also believed that the legislation prohibited only domestic emancipation, not emancipation outside of the state of Georgia. Given that interpretation, he was unwilling to insert his own interpretation. Lumpkin retreated, as did many at the time, to the argument that he would be making law were he to read the legislation differently:

4116 Ga. at *13. See also Henderson's Heirs v. Rost, 5 La.Ann. 441 (1850) (printing will that provided for limited emancipation in the opinion, while criticizing abolitionists).

$4225 \mathrm{Ga}$. at $* 7$. 
All writers on law, national and municipal, hold the same language, that the great aim should be to discover what the law-maker meant; never to lose sight of that object, and to give it effect, whatever may be our opinion of its wisdom or policy. "Whatever doubts I may have in my own breast," said Lord Mansfield, ... "with respect to the policy and expediency of this law, yet, as long as it continues in force, I am bound to see it executed according to its meaning." ${ }^{, 43}$

Lumpkin wondered what to make of his personal opposition to emancipation: "Shall I therefore undertake, by my individual opinion, to dictate to more than a half a million of my fellowcitizens, what shall be the law, by wresting these ancient statutes from what I believe to be their true and only meaning? A construction adhered to without variableness or a shadow of turning for a quarter of a century? Such is not my understanding of my duty or privilege." ${ }^{44}$

In dissent, Justice Henry Lewis Benning thought that the best way to follow the legislature's spirit was to follow the letter of the law. He believed that the freed slaves would either never leave the state or that they would return. He referred to the slaves freed by Waters' will, which had ordered them transported to Liberia. It is testimony to the trans-Atlantic nature of the late antebellum period that Benning believed at least one of those slaves had come home from Liberia. So Benning offers a realistic portrait of the nature of emancipation and how the legal system ought to respond. He distinguished the precedent that Lumpkin relied upon by noting that it was from an era of anti-slavery feelings and that it should not be followed now:

[T]hey are decisions of which the first was made before the anti-slavery sentiment had quite left us; and that the others are decisions which, as I persuade myself, merely followed the first, being made on the notion, that a precedent is to be followed, not questioned; and I say, that decisions made on that principle, cannot have as much authoritative force, as decisions made on the principle, that law is to be followed, even although a precedent has to be questioned. An echo is not entitled to rank with an original sound. ${ }_{4}$

Benning argued that courts should only follow erroneous decisions that have become common errors ("communis error"), that is "an error which must have been living and growing for a long time, so that it has its roots running and spreading every where in the community, and to tear it up, would be, to tear the community up with it." Changing the law in this case involved no such reliance interests:

Its beginning was within less than thirty years ago; its few repetitions were quite recentwithin the last dozen years; it has not a root running out into the community, for the beneficiaries of it, having gone abroad to the emancipation there prepared for them, have

\footnotetext{
${ }^{43}$ Id. (quoting Pray v. Edie, 1 T.R. 313).

${ }^{44}$ Id. at $* 10$.

${ }^{45}$ Id. at $* 14$.
} 
ceased to be a part of the community. Correcting the error, therefore, would not touch anything held by the community. True it may be, that correcting it would be disappointing expectation in the case in which the correction was made, and possibly, in some few others, those coming into existence at about the same time with that case; but this would happen, if the decision were not a decision correcting an error, but were an original decision.

So, we have a classic confrontation between precedent, legislation, and judicial sentiments and a robust defense of alteration of the law to bring it into alignment with emerging proslavery sentiments. And there is a sense in Justice Benning's opinion that law evolves in keeping with changing political and social ideas, an idea that had some currency in antebellum legal thought. Here, then, is one place where that evolution of thought might have an impact. And as we moved closer to civil war, the evolution became starker. The Mississippi Supreme Court's decision in Mitchell v. Wells, Justice Handy moved even more strongly in favor of restrictions on emancipation. ${ }^{6}$

Robert Cover's Justice Accused gave us a look at the conflicts that judges who were antislavery in private faced when they dealt with a proslavery law. ${ }^{47}$ Cases like $W$ ard give us a look at the mirror image of that problem: judges who were proslavery in private, but issued antislavery opinions (or at least faced issues of antislavery). The menu of responses is similar: attribute responsibility to the legislature or prior judges and follow "the law"; or try to change the law. In fact, there were a number of cases in which judges who proclaimed proslavery sentiment issued opinions that freed people. In addition to the series of Cleland $v$. Waters opinions and Ward, consider two opinions from 1860. First, consider Willis v. Jolliffee, decided by South Carolina Justice John Belton O'Neal, which upheld a devise to take the testators' family (who were also his property) to Ohio and free them. O'Neal upheld the devise, even over a vigorous dissent, which likened him to an abolitionist. The dissent invoked Irish abolitionist John Philpot Curran's oration about slavery and put it into the mouth of O'Neal. He closed the opinion with Curran's statement about universal emancipation:

The first moment a slaves touches the sacred soil of Britain [or Ohio] the alter and the god sink together in the dust; his soul walks abroad in her own majesty; his body swells beyond the measure of his chains that burst from around him; and he stands redeemed, regenerated, and disenthralled by the irresistable genius of universal emancipation. ${ }^{48}$

\footnotetext{
${ }^{46}$ Mitchell v. Wells, 37 Miss. (8 George) 235 (1859).

47 Robert Cover, Justice Accused: Anti-Slavery and the Judicial Process (1975).

${ }^{48}$ Curran was quoted often, by both anti-slavery and proslavery writers. See, e.g., Frederick Douglass, The Cambria Riot, My Slave Experience, and My Irish Mission: An Address Delivered in Belfast, Ireland, on December 5, 1845, in 1 The Frederick Douglass PAPERS: Series One--Speeches, Debates, AND InTERVIEWs 86 (John Blassingame et al., eds. 1979); Harriet Beecher Stowe, Uncle Tom's Cabin, chapter 37 (1852); Mary H. Eastman, Aunt Phyllis' CABin: Or, Southern Life AS IT is 95 (Philadelphia, Lippincott, Grambo \& Co., 1852).
} 
Second, consider the Arkansas opinion in Phebe v. Quillen, where Justice Fairchild interpreted an 1859 Arkansas statute that prohibited future emancipation as a prospective statute only and, thus, upheld a will executed before the statute that provided for the transportation of the testators' slaves to a free state seven years after the testator's death. ${ }^{49}$ Fairchild understood that some wanted an interpretation in favor of freedom and others in favor of slavery and he suspected there was reason to fear that proslavery sentiment might bend the law, even against poor white people. "[T]he great reaction in public sentiment in the southern States, relative to the emancipation of slaves, may produce a habit of construction so stringent as to endanger the even balance which should ever be extended to the rich and the poor, the white and the black, the free and the slave." Unfortunately, that provocative statement contained little explanation, although Justice Fairchild expressed the common proslavery idea that slaves were better off in a state of slavery than freedom. ${ }^{50}$

Lumpkin, like many other proslavery judges, was willing to shade the law towards proslavery results. In 1857 in American Colonization Society v. Gartell, Lumpkin construed narrowly the American Colonization Society's charter to limit its power to colonizing people who were already free. Thus, slaves left in a testamentary trust to the American Colonization Society, to be freed and transported to Liberia was invalidated. Lumpkin believed the Society could not free the slaves. He closed with an appeal to stop further emancipation.

I was once, in common with the great body of my fellow citizens of the South, the friend and patron of this enterprise. I now regard it as a failure, if not something wors; as I do every effort that has been made, for the abolition of negro slavery, at home or abroad. Liberia was formed of emancipated slaves, many of them partially trained and prepared for the change, and sent thousands of miles from all contract with the superior race; and given a home in a country where their ancestors were natives, and supposed to be suited to their physical condition. Arrived there, they have been for a number of years in a state of pupilage to the Colonization Society, in order that they might learn "to walk alone and by themselves." And at the end of a half a century what do we see? A few thousand thriftless, lazy semi-savages, dying of famine because they will not work! ... Under the superior race and no where else, do they attain to the highest degree of civilization; and any experiment, whether made in the British West Indian Island, the coast of Africa, or elsewhere, will demonstrate that it is a vain thing for fanaticism, a false philanthropy, or

4921 Ark. 490 (1860).

${ }^{50} I d$. at $* 5$.

The question of freedom should be determined, like every other question made before the courts, solely upon its legal aspects, without partiality to an applicant for freedom, because he may be defenseless, and a member of an inferior race, and certainly without prejudice to his kind and color, and without regard to the sincere convictions that all candida, observing men must entertain, that a change from the condition of servitude and protection, to that of being free negroes, is injurious to the community, and more unfortunate to the emancipated negro than to anyone else. 
anything else to fight against the Almighty. ${ }^{51}$

Lumpkin thought such efforts at emancipation would "disinherit" future generations. He urged opposition to emancipation via will. He concluded with an appeal to "disabuse" the older "of the false and unfounded notion that slavery is sinful and that they will peril their souls if they do not disinherit their offspring by emancipating their slaves!" 52

North Carolina, Georgia, South Carolina, and Texas judges (and Mississippi as well in the 1840s, though not later) all upheld trusts for the emancipation of slaves outside of their states. ${ }^{53}$ In 1857, Mississippi prohibited all post-mortem emancipation, even attempts at emancipation outside the state. ${ }^{54}$

Later in the antebellum period, judges in Alabama and Mississippi opted the more proslavery position of making the law even more proslavery than it had been in other jurisdictions. Alabama's Supreme Court construed broadly the Alabama statute limiting emancipation via will in Trotter v. Blocker in $1842 .{ }^{55}$ In a short opinion in Carroll v. Brumby Justice Dargan narrowly construed a will in which the testator had offered slaves a choice of freedom and transportation outside the state or continued servitude for his daughter. The testator in Carroll offered the slaves a choice of being transported to Liberia where they

51 Mississippi took a similar path in denying the American Colonization Society's power to take bequests of slaves. See Lusk v. Lewis, 32 Miss. (3 George) 297 (1856) (refusing to allow trustees to take bequest of slaves for the benefit of the American Colonization Society, because the Society's charter only allowed them to colonize, not own people). See also Lusk v. Lusk, 35 Miss. (6 George) 401 (1858) (refusing to allow American Colonization Society to take $\$ 3500$ bequest).

$5223 \mathrm{Ga}$. at $* 11$.

${ }^{53}$ Cox v. Williams, 39 N.C. (4 Ired. Eq.) 15 (1845) (upholding gift of humans to American Colonization Society); Jones v. Gordon, 55 N.C. (2 Jones Eq.) 352 (1856); Purvis v. Sherrod, 12 Tex. 140 (1854); Ross v. Vertner, 6 Miss. (5 Howard) 305 (1840); Frazier v. Frazier, 2 Hill's Ch. R. 305 (1835); Vance v. Crawford, 4 Ga. 445. Justice Lumpkin concluded in Vance that devises that tended to disrupt family relations should be disregarded-precisely because they tended to disrupt:

If it be true ... that families are the original of all societies, and contain the foundation and primitive elements of all other social institutions, and as such deservedly claim the front rank in the protection of Courts, Wills, which are calculated pratically, to disregard and set at nought this divine ordinances, worth more than all that man in his wisdom has ever devised, cannot claim to be regarded with peculiar tenderness and favoritism by Courts of justice.

1848 WL 1510 , at *11.

${ }^{54}$ See Mitchell v. Wells, 37 Miss. at *28 (quoting Statute of 1857, Rev. Code 236, art. 9).

${ }^{55} 6$ Porter 269 (Ala. 1842) (citing 1834 Alabama legislation on emancipation). 
would be freed or staying in slavery in Alabama; the Alabama Supreme Court found that the slaves did not have the legal capacity to make that choice. The testators' intestate heirs claimed that the slaves were not entitled to make such a choice and that, therefore, the entire provision failed and that the slaves should be part of the testator's intestate estate. The court rejected that extreme position and also the possibility of emancipation and left the slaves to the daughter. ${ }^{56}$

At its January 1861 term, the Alabama Supreme Court again rejected an attempt in Creswell's Executor v. Walker to give slaves the option of obtaining freedom by leaving the state. The Court once again upheld Brumby, even as it realized that it was the majority of precedent from slaveholding states permitted slaves to choose whether to be transported to

5613 Ala. 102 (1848) (with citation of only one case, Trotter v. Blocker, 6 Porter 269 (1842)). The progression of cases in Alabama that prohibited emancipation via will after Carroll included Alston v. Coleman, 7 Ala. 795 (1845); Harrison v. Harrison, 9 Ala. 470 (1846); Welch's Heirs v. Welch's Adm'r, 14 Ala. 76 (1848) (following Carroll v. Brumby), Pool v. Harrison, 18 Ala. 514 (1850), Roberson's Heirs v. Roberson's Ex'rs, 21 Ala. 273 (1852) (citing only Trotter), through Evans v. Kittrell, 33 Ala. 449 (1859). However, Atwood's Heirs v. Beck, 21 Ala. 590, allowed some room for emancipation under a trust. Atwood's Heirs was followed in several cases, Abercrombie v. Abercrombie, 27 Ala. 489 (1855) (in which a testator instructed a trustee to "treat[] them with humanity according to the position they occupy in society, and see that they are not imposed upon by others" until the youngest of the children reached age 21 , then to emancipate them in Alabama if that is legal or to take them outside the state for emancipation) and Hooper v. Hooper, 32 Ala. 669 (1858) (citing Atwood's Heirs, as well as a North Carolina opinion that was generous in interpretation of a trustees' power to emancipate, Thompson $v$. Newlin, 8 Ired. Eq. 32).

Abercrombie is of particular interest because in that case Justice Goldthwaite upheld what might very well have been a trust for quasi-freedom. He did so by acknowledging that the trust might be for a prohibited purpose, but found insufficient evidence for that. Moreover, he acknowledged the moral duty to treat slaves humanely. Hence, the law took its direction in some way from the proscription of morality, in that it approved of a suspicious trust on the ground that the patent terms of the trust were consistent with the dictates of morality. Though Justice George Goldthwaite cited no source for his proscription that "It is the moral, if not the legal duty, of every master or owner, to observe towards his slaves the same general course of conduct, which the testator in these directions prescribed; and this being the case, we cannot say that there is anything illegal in them." 27 Ala. 489 at*3. Goldthwaite cited only one case-the North Carolina opinion in Washington v. Blunt, 8 Ired.Eq. 253 (1852), which nominally rejected a trust for quasi-freedom, but upheld a provision of a trust the allowed enslaved people to choose the continued slavery or freedom. Perhaps Goldthwaite is yet another justice who subtly worked to shape an antislavery law, even in that most zealously of proslavery jurisdictions.

On the eve of the Civil War, the Alabama Supreme Court similarly rejected contracts among white people regarding emancipation of slaves. Evans explicility overruled Prater $v$. Darby, 24 Ala. 496 (1854) (though not Atwood's Heirs), which upheld a contract to emancipate. 
another state and freed or maintained in slavery. ${ }^{57}$ The court acknowledged that Thomas R.R. Cobb's treatise on slavery-a leading work on proslavery thought and law--criticized Brumby. ("The theory of a complete annihilation of will in the slave, is utterly inconsistent with all recognition of him as a person, especially as responsible for criminally for his acts." $)^{58}$ The court revisited its treatment of slaves' legal capacity and reaffirmed the distinction between holding slaves liable for criminal acts and permitting them authority to decide their fate. The issue was "can a master, by his will, clothe his slaves with the irrevocable power of determining and changing, by an uncontrollable act of their will, their own civil status?" The court held no. It distinguished between civil acts (for which slaves were not considered person-or as we might phrase it now, citizens) and criminal acts, for which slaves had liability. The court also distinguished cases where slaves were responsible as the agents of their masters. ${ }^{59}$ It starkly concluded "Because they are slaves, they are not necessarily, and, so long as they remain slaves, incurably, incapable of performing civil acts; and, in reference to too all such, they are things, not persons." ${ }^{60}$ Or, in words reminiscent of Harriet Beecher Stowe's reference in Uncle Tom's Cabin to "the man that was a thing," the court said, "in respect of civil rights and legal capacity to perform acts of a civil nature, the slave is not a person, but a thing." ${ }^{61}$ Because the slaves could not be consulted to determine what should happen under the trust, the trust could not be completed and the trust failed. ${ }^{62}$ Even in the face of contrary precedent from other states, Alabama continued to limit emancipation via will until the Civil War.

On the eve of the Civil War, in 1859, a divided Mississippi Supreme Court refused in Mitchell v. Wells to even allow a freed person who lived in Ohio to take a bequest from her

5737 Ala. 229 (1861). Among the cases that the Crewsell court cited were Washington v. Blunt, 8 Ired. Eq. 253; Jordan v. Bradley, Dudley's R. 170; Frazier v. Frazier, 2 Hill's Ch. 305; Cleland v. Waters, 19 Geo. 35; Ross v. Vertner, 5 How. Miss. 305; Leech v. Cooley, 6 Sm.\& M. 93; Graham's Exec. v. Sam, 7 B. Monroe 403; John v. Moreman, 8 B. Monroe 100; Adams v. Adams, 10 B. Monroe 20; and Isaac v. McGill, 9 Humph. 616; Wade v. Am. Col. Society, 7 Sm. \& M. 694. See 37 Ala. at 229, *2.

58 Thomas R.R. Cobb, Inquiry into the Law of Negro Slavery in the United States (1858). Cobb, though, thought Carroll v. Brumby was incorrect in its rigid refusal to allow emancipation.

${ }^{59} 37$ Ala. at $229 * 6$ (distinguishing State v. Hart, 26 N.C. 246, 4 Ired. 246 (1844)).

${ }^{60}$ See also id. at *4 ("Such a bequest is an effort on the part of the testator to impart to slaves rights which belong exclusively to freemen,--thus placing them in that middle state between absolute freedom and absolute slavery, which our law, upon grounds of paramount public policy, refuses to recognize as legally possible.").

6137 Ala. at $229 * 5$.

${ }^{62}$ Id. at $* 7$. 
father when he died in Mississippi. ${ }^{63}$ Counsel in Mitchell relied upon Georgia lawyer Thomas Cobb's Historical Inquiry into the Law of Negro Slavery for substantial parts of their argument about the slaves' limited rights to citizenship and their limited rights to access to the courts. Other counsel used similar arguments. In arguing that a Mississippi will was void because it attempted to provide for the transportation of several slaves outside of the state for emancipation, counsel concluded that slavery was necessary:

The normal condition of the African is servitude. Slavery is his earthly paradise. Experience attests this truth, and vindicates its Divine authority. The man who will disregard this truth, and violate this law of Heaven, should be treated as an enemy to society, as civiliter mortuus, and as wholly incapable of making a valid testament. He is doing an injury to society. His act is calculated to unsettle the peculiar institutions that surround us. ${ }^{64}$

The majority in Mitchell drew upon images of exclusion of slaves from citizenship and from history to understand what the state's policy ought to be. The court went beyond Justice Lumpkin's decision in Cleland v. Waters ${ }^{65}$ which looked to Georgia legislation. The court thought it true that the state's statutes and constitution "afford the highest, most usual, direct, and positive evidence of that policy, but not the only sources of evidence from which to ascertain it. Her whole condition, circumstances, and history may, in connection with her constitution, laws, resolutions, and public acts, be adduced and relied on as evidence of her public policy." ${ }^{166}$ Justice Harris goes on to draw from Thomas Cobb's treatise "(a work distinguished alike for ability, research, and a clear and lucid presentation and arrangement of the subjects of which he treats"), for evidence of slavery's ubiquity and to make the case that slavery is natural and that it exists independent of local law.

Wade v. American Colonization Society, decided in Mississippi in 1840-two years before the statute that prohibited testators from ordering their slaves be transported out of state and freed ${ }^{67}$ was overruled in the next decade by Lusk v. Lewis. ${ }^{68}$ Nevertheless, while Mississippi consistently upheld the prohibition, it limited the prohibition in some ways. When a testator attempted to get around the 1842 prohibition on emancipation even outside the state, the

${ }^{63}$ See Mitchell v. Wells, 37 Miss. at *10. Alabama had earlier, in 1852, allowed a freed person in Ohio to receive a bequest. See Atwood's Heirs v. Beck, 21 Ala. 590 (1852).

${ }^{64}$ Cheairs v. Smith, 37 Miss. (8 George) 646 (1859).

$6519 \mathrm{Ga} .43$,

${ }^{66}$ Mitchell v. Wells, 37 Miss. (8 George) 235 (1859) at*16.

${ }^{67}$ Wade v. American Colonization Society, 15 Miss. 663 (1840).

${ }^{68} 32$ Miss. 297 (1856), as discussed in Mitchell v. Wells, 37 Miss. (8 George) 235 (1859); Mahorner v. Hooe, (9 S\&M) 247 (upholding Mississippi legislation that restricts emancipation beyond the state). 
Mississippi Court of Errors and Appeals still construed the law narrowly. The statute had prohibited the emancipation of slaves by will or to direct slaves to be taken out of Mississippi for emancipation. The court would thus invalidated a bequest to the American Colonization Society, but allowed a residuary heir to take the slaves who were intended to be free. "The design of the Act... was not to interfere unnecessarily with the great and sacred right of testamentary disposition." ${ }^{69}$ There were suspicions that the residuary heir might free the slaves under a secret trust, but the court did not look into such allegations further. ${ }^{70}$

Other trusts to free were looked upon with great skepticism; thus, trusts that placed slaves in a state of "quasi-freedom," where they were "owned" by the trust but given great latitude by the trustees, were routinely invalidated. ${ }^{71}$

The old South is a place where we think that families matter and inheritance is important. Turning now to the evidence from Greene County at the high point of the old South's economy allows us to take a picture of the ways that wealth was transmitted and to capture what affluent testators did with their property.

\section{The Probate Process and Greene County, Alabama, 1831 to 1845}

While some write about curtailing inherited wealth today, ${ }^{72}$ and some did so as well in the nineteenth century, ${ }^{73}$ those in the old South held more positive attitudes towards inherited wealth. For it was a place where family and tradition and wealth mattered, as generations of historians have taught us. ${ }^{74}$ And the law recognized and respected those traditions as well.

${ }^{69}$ Garnett v. Cowles, 39 Miss. (10 George) 60 (1860).

70 See id. at *14 (arguments of counsel, pointing to a letter in the Liberia Advocate, a paper of the American Colonization Society, where testator discussed his intentions in the will).

71 John Hartwell Cocke, a leading member of the American Colonization Society, established what appears to be a state of quasi-freedom in Greene County during the period studied here. During much of the period, Cocke lived in Virginia and he overseer ran the plantation in what appears to have been a state of quasi-freedom. See G. Ward Hubbs, Guarding Greensboro: A Confederate Community in the Making of a Southern Community 64-67 (2003).

72 See, e.g., Mark Ascher, Curtailing Inherited Wealth, 89 Mich. L. REV. 69 (1990); MiCHAEL J. Graetz \& Ian Shapiro, Death by a Thousand Cuts: The Fight Over Taxing Inherited Wealth (2005); Jens BecKert, Inherited Wealth (2007).

73 There were some voices calling for more radical redistribution of property. But they seem to have been rather rare. See, e.g., Thomas Skidmore, The Rights of Man to Property! (1829). The power of property to bring civilization was a popular theme in the old South and elsewhere in antebellum America. See, e.g., Alfred L. Brophy, How Missionaries Thought: About Property, For Instance, 30 U. HawaII L. REV. 373-99 (2008).

74 See, e.g., Eugene Genovese and Elizabeth Fox-Genovese, The Mind of the Master Class (2005); Michael O’Brien, Conjectures of Order (2005). 
When the North Carolina Supreme Court faced a novel question about distribution of real property to remote kin in 1854 via intestacy, it acknowledged the centrality of feelings of affection for family members. ${ }^{75}$ Such feelings of kinship, whether expressed in a state's intestacy law or in wills left by individuals, were central to American culture. This is likely particularly true in a place like affluent Greene County, a strong-hold for Whig politics, which emphasized commercial interests. ${ }^{76}$

\section{A. Intestacy in Alabama, 1830-1845}

The baseline against which we should judge the testamentary devises is the intestate scheme. During the period of this study-1831 to 1845 -Alabama provided that a surviving widow was entitled to a one-third share of the decedent husband's estate, if there were surviving

${ }^{75}$ Clement v. Cauble, 55 N.C. 82, 2 Jones Eq. 82 (1854):

It is a principle founded on natural feeling, that upon the death of the owner, without making a disposition of it, his estate shall belong to his "next of kin." It is also a principle, which, although subservient to the former, is likewise founded on natural feeling, that one should not be excluded from a share of the estate of his deceased kinsman, if by representing an ancestor he can bring himself up to an equality with those who are the "next of kin." Upon these two general principles the distribution of estates, both real and personal, is based as the "corner stones."

Clement involved distribution of property via intestacy; all the cases studied here involved wills. However Clement illustrates the understanding of courts of the centrality of kinship.

76 See Thornton, supra note 3, at 41 (drawing upon data in Report of the Comptroller of Public Accounts on the Subject of Taxation 13-21 (Montgomery, McCormick \& Walshe, 1848) for evidence of Greene County's contribution to banks, a key indicator of their commercial orientation); Lawrence F. Kohl, The Politics of Individualism: Parties and the AMERICAN CHARACTER IN THE JACKSONIAN ERA 63-99 (1989) (discussing Whig ideology).

Additional evidence on antebellum Greene County is available in Lee Wayne Rahe, Residential Furnishings of Deceased Greene County, Alabama Slave Owners: 1845-1860 (1992) (mining probate inventories for evidence of material lives of Greene County slaveholders); Clay Lancaster, Eutaw: The Builders and Architecture of An Antebellum Southern Town (1977); Kimberly R. Jacobson, Greene County and Mesopotamia Cemetery (2007); Harold Woodman, Slavery and the Southern Economy (1966) (employing tax records from Greene County). Some of the intellectual culture of Greene County appears in Joseph W. Taylor, Henry Clay, His Life, Character and Services: An Oration Delivered before a Meeting of the Citizens of Greene County, Alabama, at Eutaw, July 31st, 1852 (1852). On post-war Greene County, see Michael W. Fitzgerald, Extralegal violence and the Planter Class: The Ku Klux Klan in the Alabama Black Belt During Reconstruction, in Local Matters: Race, Crime, AND Justice In the Nineteenth Century South 155 (Christopher Waldrep \& Donald G. Nieman eds., 2001). 
children. The remainder of the estate was distributed in equal shares to the surviving children. ${ }^{77}$

As with the Statute of Frauds, Alabama requirements varied depending on whether the testator gave personal or real property. For personal property, neither witness or testator signatures were required, but only that the will be in the handwriting of the testator if written or "made in the [testator's] last sickness" if oral, or nuncupative. The requirements for real property were identical to those in the Statute of Frauds, but with a slight exception to the witnesses' prong. While three witnesses were still necessary, their signatures in the testator's presence - a formality borrowed from the Wills Act - was also required. As a result, Alabama's law was more stringent than either of the preceding laws.

Rules of construction were also well developed. Of special importance was the testator's intent. If necessary, courts were afforded the liberty to "transpose[], suppl[y], or reject[]" "words and limitations." For example, an "'or"" and an "'and"” were interchangeable, and an "if" " could replace a "when." Mistakes, however, as a general rule, could not be corrected, unless the mistake was clear upon looking at the will alone or the mistake concerned the legatee's name and "there [was] no reasonable doubt as to the person intended."

Lastly, Alabama's probate laws regarding the property rights of the surviving spouse were quite unique. Prior to 1847, a widow's dower right was one-half of her deceased husband's estate if there were no children or one child, an equal division if there were two to four children, and one-fifth if there were five or more children. This illustrates the property rights-limited though they might be-that even married women retained during the antebellum era. ${ }^{78}$ Exceptions were provided in the case of subsequent marriages. Recognizing the likelihood of blended families, the law provided that a woman was capable of making a will "in pursuance of an agreement before marriage."

\section{B. Wills in Greene County, 1831 to 1845}

The probated wills come from Greene County, Alabama in two periods: 1831 to 1835 and 1841 to 1845 . By focusing on these relics that were executed and probated prior to the Civil War, one can examine the practice of wealth transmission, particularly wealth in humans, through the perception of the testator. The disposition of such persons was central to a majority of wills. Additionally, unique testation patterns throughout these wills, especially with regard to

\footnotetext{
77 John A. Cuthbert, Compendium of the Law of Executors, Administrators, Guardians and Dower, in Force in Alabama 2-4 (1850). As to the sickness requirement, it "must have been made at the habitation of the deceased, or where he had resided ten days or more, next preceding the making of the will; unless he were taken sick abroad, and died before his return home." Id. at 4.
}

78 Richard Chused demonstrates the power of married women over property in a series of articles. See Richard Chused, Married Women's Property Law: 1800--1850, 71 GeO. L. J. 1359-1425 (1983). Chused's empirical work on Masshacusetts wills, over a longer period of time than studied in Greene County here, shows a dramatic increase in property left to women over the first half of the nineteenth century. See Richard Chused, Married Women's Property and Inheritance by Widows in Massachusetts: A Study of Wills Probated Between 1800 and 1850, 2 Berkeley Women's L. J. 42--88 (1986). 
the mid-nineteenth century, are scarce but emphasize practices that would latter become commonplace. For example, the declining use of favored distribution ${ }^{79}$ and the creation of trusts to convey certain properties are evidenced amongst the wills sampled. Ultimately, the combination of this empirical data with its historical context enables this study to explore the diverse purposes the probate system served.

\section{The Setting: Greene County, Alabama}

Bearing the name of Revolutionary War General Nathaniel Greene, Greene County was formed by the first Alabama legislature on December $13,1819,{ }^{80}$ more than ten years prior to the earliest will of this study. Its boundaries were wider prior to 1867, when the county was divided and "all of the county lying east of the Black Warrior River" became Hale County. Such abundant acreage, which then included the booming town of Greensboro, became valuable territory for those first inhabitants. Its early settlers, arriving from Virginia and Connecticut, as well Nova Scotia, Ireland, and Germany, "[a]1l came to make their fortunes." S1 Some of the stories about the county's settlement draw upon romantic imagery associated with the moonlight and magnolia school. University of Alabama English Professor Carl Carmer's 1934 book Stars Fell Upon Alabama, for instance, tells of the settlement of Greene County in the 1820 s. In writing about the Greene County plantation Thornhill, Carmer wrote of its history:

James Innis Thornton was the name of the gallant Revolutionary solider from Fall Hill Plantation in Fredericksburg, Virginia, who, riding through Alabama on the staff of the escort to General Lafayette in 1825, resolved to build a home there. He purchased the land for it when he returned to Alabama, four thousand acres of the fertile valley that lies between the forks of the Tombigbee and Warrior rivers. And he brought with him six other young men, his friends form around Fredericksburg, all with their brides; and every family built a house on a hill-so that each hill of a curing chain was crowned with a Virginia home. They made a long gay caravan traveling southward from the Old Dominion, the gentlemen riding beside their wives' carriages, behind them the mounted overseers bringing on the wagon train filled with household good and farming tools and slaves. ${ }^{82}$

79 See SHAmmas, supra note 10, at 66-67 (noting that the English system of primogeniture, which provided "[p]referential treatment [for] eldest sons and male heirs," was largely abandoned in America by 1800).

801 Thomas McAdory Owen, History of Alabama and Dictionary of Alabama BIOGRAPHY 669 (1921). Snedecor's Map of Greene County, is available on the internet: http://alabamamaps.ua.edu/historicalmaps/counties/greene/greene.html

${ }^{81}$ HubBs, supra note 71 , at 7.

82 Carl Carmer, Stars Fell on Alabama 94 (1934). Carmer continued: 
"The land that attracted them was known as the Canebrake, in Alabama's Black Belt and bordered roughly on the east and west by the Cahaba and Black Warrior Rivers." 83 The "Black Belt" was the name given to that section of Alabama where the rich, black soil led to extensive cultivation during the antebellum period. ${ }^{84}$ It is also, not coincidentally, the section where slavery flourished the most. ${ }^{85}$ The Canebrake, however, was penned for the voluminous amounts of cane or bamboo that grew along the rivers and creeks of that area. The extensive growth of such plants was the result of soil from "the richest part of the Black Belt," leading many to believe that such was "the best soil in the South, ideally suited for growing cotton."

And cotton certainly became central to the Greene County economy during its early years, with its farmers producing approximately 8,000 bales by 1840 and almost 58,000 by 1860 . In fact, Greene had the third or fourth highest production rate in the state during this period. Cotton, however, was not the only crop bringing riches to the plantation owners. Slaves took advantage of the plush Canebrake region by producing 520,000 bushels of corn in 1840, as well as peaches, sweet potatoes, oats, rye, and wheat. Not surprisingly, Greene had the most "land in production" amongst all the counties of the state and "had nearly as much improved land as unimproved, a percentage exceeded by only two other Alabama counties during the antebellum era." The implications of the agricultural industry were also evidenced in a number of the wills sampled. Many testators, mindful of their debts at death, requested their executors to sell their crops after their decease and use the proceeds to pay off creditors, with the remainder benefitting surviving family members.

Also essential to Greene County during this era was its population and racial makeup. The desire for land and increasing commerce inevitably resulted in a rising population, from 4,500 total residents in 1820 to 15,000 total residents in 1830, making Greene the "second most populous county" in the state. ${ }^{86}$ By 1840 , the county had grown to approximately 24,000 residents. ${ }^{87}$ In 1820, the population was 1,693. By 1840, however, the African American population had more than doubled that of the white population: 16,468 compared to 7,556 . Such numbers are significant, though not surprising, considering the large number of testators who, at death, offered up their slaves for hire or bequeathed them to surviving family members and friends. In sum, an understanding of the demographics, thriving economy, and landscape of

These young gallants had known General Washington. Thornton, indeed, was the great man's cousin. They had seen Mount Vernon and Kenmore and the other famous early American houses and they intended to build as well. If Thorn Hill may be a criterion, they succeeded.

${ }^{83}$ HubBS, supra note 71 , at 7.

842 OWEN, supra note 80 , at 935.

85 J. Harvie Wilkinson, III, The Supreme Court and Southern School Desegregation, 1955-1970: A History and Analysis, 64 VA. L. REV. 485, 496 (1978).

${ }^{86}$ HubBS, supra note 71, at 7.

871 OWEN, supra note 80, at 670. 
Greene County during this era helps provide the context within which these wills were created.

\section{The Methodology}

Drawing upon the methodology of Lawrence Friedman, Christopher Walker and Ben Hernandez-Stern in a study of wills in San Bernadino County, California, this study mines wills for data about how the probate system was used. ${ }^{88}$ It analyzes 110 wills from the records of the Greene County, which are housed at the courthouse in Eutaw. ${ }^{89}$ Every will that appeared in the will books from two five-year periods - 1831 to 1835 and 1841 to 1845 -were employed in the study, with the exception of a small number that were defaced or incomplete and thus unusable. What was key for this study was the period when wills were probated, rather than when they were written. Thus, a will that was executed in 1836 and probated in 1842 would be included in the study. If there was no record of probate available, the year of execution was used to determine eligibility for inclusion in this study. There are additional probate records for some of the wills, largely inventories of estate. A small number of the inventories of estate were sampled; however, the primary focus of this study are the expression of testators' wishes in the probated wills, rather than the probate procedure itself.

After we identified the 110 useable wills probated in 1831 to 1835 and 1841 to 1845 , each will was summarized, taking account of several key elements, including the personal and real property that was disposed of, the presence (or lack) of a familial relationship between the testator and each beneficiary, preferences between heirs, the use of trusts, and other peculiar conditions and conveyances.

Aggregate census data from both 1830 and 1840 were also employed, primarily to get a general idea of how the testators examined in this study fared with the rest of the general population in terms of wealth, gender, marital status, the number of family members within each household, and the number of persons owned by the testator. The results were tabulated and contrasted with any records of probate that may have accompanied the wills, early nineteenth century legal treatises, and any Alabama appellate court opinions that may have affected any of the wills examined. While these additional sources helped to establish the context within each will operated, deference to the four corners of the will itself remained the linchpin of the entire study.

\section{Patterns of Testation, Greene County, Alabama, 1831-1845}

Those who used the testate process in antebellum Greene County were affluent and they became more so in the period after 1840 . They used wills primarily to distribute property to their spouses and children and some of them used sophisticated trusts to provide for the support and education of their spouses and issue.

${ }^{88}$ Lawrence M. Friedman, et alia, The Inheritance Process in San Bernardino County, California, 1964: A Research Note, 43 Houston L. Rev. 1445 (2007).

${ }^{89}$ Prior to 1838, Greene's county seat was at Erie, a town along the Black Warrior River, now abandoned. The place where Erie was, is now in Hale County, near Greensboro. 


\section{A. Who were the testators?}

Wills, like many other parts of the law, were predominantly the domain of men in the antebellum era. Of the 31 testators studied from 1831 to $1834,83.9 \%(\mathrm{~N}=26)$ were men; the remaining $16.1 \%(\mathrm{~N}=5)$ were women. (Table 1, Testators by Gender, 1831-35) ${ }^{90}$ Of the 79 testators studied from 1841 to $1845,86.1 \%(\mathrm{~N}=68)$ were men; the remaining $13.9 \%(\mathrm{~N}=11)$ were women. (Table 2, Testators by Gender, 1841-45; Table 3, Testators by Gender, 1831-45)

This gender imbalance is in keeping with other studies of testators around the same time. Carole Shammas reported that 5.6 percent of the testators were female in Bucks County, Pennsylvania from 1791 to $1801 .^{91}$ Lawrence Friedman found that female testators comprised 3.3 percent of the wills in 1850 Essex County, New Jersey, while that figure increased to 21.6 percent in $1875 .^{92}$ T.P. Schwartz's study of Providence, Rhode Island wills revealed that 19 percent of testators from 1775 to 1790 were women. ${ }^{93}$

Wills were also the domain of wealthy men. Of the 26 male testators from 1831-35, $92.3 \%(\mathrm{~N}=24)$ included at least one slave in their bequests. A majority of female testators in that period $(60 \%, \mathrm{~N}=3)$ also included at least one slave in their bequests. (Table 4, Testators Who Owned People, 1831-35) Of the 68 male testators from 1841-45, 75\% (N=51) mentioned at least one slave in their bequests; again a majority of females in the period $1841-45(72.7 \%$, $\mathrm{N}=8)$ mentioned at least one slave in their bequests. Overall, nearly four of five wills $(78.1 \%$, $\mathrm{N}=86$ ) of the complete sample of 110 mentioned at least one slave in their bequests. (Table 5, Testators Who Owned People, 1841-45; Table 6, Testators Who Owned People, 1831-45) As one would expect from such a wealthy county, slave-owners predominated among Greene County testators.

One can bring further precision to studying the wealth of the testators by matching them with census records. Of the 110 testators in this study, $92(83.6 \%)$ were located in either the 1830 or 1840 census. Obviously, testators who died in the 1831-35 period could only appear in the 1830 census. For those who died in the 1841-45 period, they were searched first in the 1840 census. If no match could be made for them in the 1840 census, then they were searched in the 1830 census. Two additional testators were located in this way.

The census records, which record the number of slaves person owned, help fill out the picture of the wealth of the Greene County testators. Of the 31 testators in the 1831-35 period, we 27 were located in the 1830 census. Of those 27 people, 24 testators or $88.9 \%$ owned at least one person. Of those slaveowning testators, 20 were men and four were women. Five of those testators $(18.5 \%)$ owned at least twenty people. One of those five testators who owned more

90 All of the tables referenced in this paper are available at: http://blurblawg.typepad.com/files/greenecountytables2-1.doc

91 Shammas, supra note 10, at 16.

92 Friedman, supra note 88, at 36.

93 T.P. Schwartz, Durkheim's Prediction About the Declining Importance of the Family and Inheritance: Evidence from the Wills of Providence, 1775-1985, 37 Soc. Q. 503, 510 (1996). 
than twenty people was a woman. (See Table 7, Number of Slaves Owned by Testators, 183135, Federal Census.) The testators from the second period, 1841-45, were similarly affluent. Of the 79 testators in the second group, 65 were located in the 1840 or 1830 census. Of those 65 people, 54 testators $(83.1 \%)$ owned at least one person. Among the slaveowners, there was even more human wealth than in the 1831-35 group. For 20 of the 54 testators (37\%) owned more than twenty people. (See Table 8, Number of Slaves Owned by Testators, 1841-45, Federal Census; Table 9, Number of Slaves Owned by Testators, 1831-45, Federal Census.)

\section{B. What Did Testators Do With Their Wealth?}

Those wealthy testators chose, by and large, to leave their wealth to their family. This is in keeping with our hypothesis that in the old South, where family was particularly important, testators would leave property primarily to their close family members. What seems particularly important-although the exact importance must await comparative studies with testators in northern and western states-is the extent to which married testators limited the power of their widows to property if they remarried.

\section{Married Testators}

Among those who had spouses, all the testators were male and all except one left at least something to their surviving spouses. In the period 1831-35, 18 of the 31 testators were married. All were male and all except one left $(\mathrm{N}=17)$ at least some of their property to their surviving widows. A larger percentage of them also left property to their children $(77.7 \%, \mathrm{~N}=14)$ and a smaller percentage chose to leave at least part of their estate to other close relatives $(20 \%, \mathrm{~N}=4)$. (See Table 10, Objects of Bounty of Married Testators, 1831-35) Not one of them left any property to other people. That is, those who died while married kept the property within the family.

In the period 1841-45, 49 of the 79 testators were married (62\%). All were male and all left something to their surviving spouse. A significant percentage of them $(87.7 \%, \mathrm{~N}=43)$ also left something to their children; a significant minority $(24.4 \%, \mathrm{~N}=12)$ left something to other close relatives and an even smaller percentage $(18.3 \%, \mathrm{~N}=9)$ left some property to other persons. (See Table 11, Objects of Bounty of Married Testators, 1841-45; Table 12, Objects of Bounty of Married Testators, 1831-45).

For those testators who were married at the time of their death, there is the additional question, how much did they leave to their surviving spouses? Prior to 1847, Alabama law provided for a widow's dower right of one-half of her deceased husband's estate if there were no children or one child, an equal division if there were two to four children, and one-fifth if there were five or more children. ${ }^{94}$ Over the entire period of this study, of the 67 testators who were married at the time of the execution of their wills, 35.8\% $(\mathrm{N}=24)$. A majority $(56.7 \%$, $\mathrm{N}=38)$ left more than one-third of their estate to their surviving spouse, either outright or in a life estate; only $7.3 \%(\mathrm{~N}=5)$ left less than one third of their estate (in one case nothing) to the surviving widow. (See Table 13, Distribution to Widows, 1831-35; Table 14, Distribution to Widows,

${ }^{94}$ Cuthbert, supra note 70 , at 82. 
1841- 45; Table 15, Distribution to Widows, 1831-45). Tables 16, 17, and 18 bring a little more precision to the nature of the distribution to widows. They report the kind of estates left to the widow-an estate in widowhood (that is until remarriage or for life), life, or a fee simple estate. (See Table 16, Interest Conveyed to the Spouse, 1831-35; Table 17, Interest Conveyed to the Spouse, 1841-45; Table 18, Interest Conveyed to the Spouse, 1831-45).

Many testators left their entire estate to their surviving wife for life, with instructions to divide the estate upon the widow's death-an estate for widowhood. ${ }^{95}$ In other cases, wives were left the property with a restriction that if they remarried, they would receive a smaller share (described variously as the legal portion or a child's share). Thus, William Bell's will probated in 1834, left all his property to wife for life, then to Bell's children upon her death. ${ }^{96}$ Alexander Dobbins, whose will was probated in 1844, left his entire plantation went to his wife for life, but stipulated that if she remarried, the plantation would go to his son. The plantation's livestock was to be equally divided among Dobbins' children..$^{97}$ Jeremiah Whitworth's will, probated in 1842, provided for his wife for life "or widowhood." If she remarried, should would receive an intestate share and the estate would be sold. The son would receive half and the three daughters and their issue would share the remaining one-half. ${ }^{98}$ Similarly, William Stevens' will, probated in 1834, provided that the plantation would be run by his executor and the profit used to educate his children. Children would receive their "legal proportion" upon reaching age of majority and his wife would receive her "legal proportion" if she remarried. ${ }^{99}$ Samuel Cherry's will, probated in 1844, provided that his wife would have possession of his estate during her life or widowhood and that if she remarried, she would receive a child's part (apparently a 1/7 share with Cherry's six children). ${ }^{100}$

Other testators left at least a part of the estate outright. Thus, James Martin's 1834 will left his Greene County property to his wife and his Marengo County property to his son. His

95 See, e.g., Powell v. Powell, 10 Ala. 900 (1846) (discussing in syllabus of the case, estate for widowhood).

96 William Bell's Will, Greene County Wills Book B, at 153.

97 Alexander Dobbins' Will, Greene County Wills Book B, at 281. See also James W. Hall's Will (1834), Greene County Wills Book B, at 150 (providing that wife was to have all property for life, but upon remarriage, property would be divided equally with her three children; upon wife's death without remarrying, two sons would share the estate); Thomas Wilcox's Will (1834), Greene County Wills Book B, at 139 (providing for wife for life, then distributing property, including stock in the "Manchester Petersburg Turnpike" to his grandchildren).

98 Jeremiah Whitworth's Will, Greene County Wills Book C, unnumbered page.

99 William Stevens' Will, Greene County Wills Book B, at 155.

100 Samuel Cherry's Will, Greene County Wills Book C, at 63. Cherry also provided that one of his sons would receive a college education out of the estate. See also Blaney Brand's Will, Greene County Will Book B, at 301 ("if my wife should prefer to have a child's part, that will be set apart to her"). 
wife held the son's property in trust until the son turned age $21 .{ }^{101}$

\section{Unmarried Testators}

When there was no surviving widow, the objects of the bounty were more dispersed. Among the 13 testators who had no surviving spouses in the 1831-35 sample, most left some of their property to children (60\%). Other close relatives (grandchildren, siblings and parents) also received at least part of the testators' estates in half of the cases. Only about one-third of estates $(\mathrm{N}=)$ left any property at all to other people (who?--includes nieces, nephews, cousins, aunts, uncles, brothers-in-law, sisters-in-law, persons owned, and friends of the testator). (See Table 19, Objects of Bounty of Unmarried Testators, 1831-35.) Similarly, among the 30 testators in the 1841-45 sample who were single or widowed, the majority $(60 \%, \mathrm{~N}=18)$ left at least some property to children; even more $(73.3 \%, \mathrm{~N}=22)$ left at least some property to other close relatives, and-as with $1831-35$, about one third $(30 \%, \mathrm{~N}=9)$ left at least some property to other people. (See Table 20, Objects of Bounty of Unmarried Testators, 1841-45; Table 21, Objects of Bounty of Unmarried Testators, 1831-45).

In cases where testators had children and their spouses had predeceased them, testators frequently left a substantial portion of their estate to those children. For example. In other instances, when testators has no spouse and no children, they frequently distributed their estates to siblings and nieces and nephews. Thus, Jane B. Page, whose will was probated in 1841, left most of her property to her siblings, but also provided for at least one slave to be put in trust for a niece who was under age $21 .^{102}$

101 James Martin's Will, Greene County Wills Book B, at 149.

102 Jane B. Page's Will, Greene County Wills Book B, at 280-81. A codicil subsequently revoked the trust and provided for an outright bequest to the niece, perhaps because the niece reached age of majority. Id. at 282. Only six testators throughout both samples died married with no children. All of them provided for there wives, while others provided for other relatives as well. For example, Posey Gordon left all of his property to his wife, but at her death, it was to be equally divided amongst his children (although it appears he did not have any children at the time the will was executed). Posey Gordon's Will, Greene County Wills Book B, at 60-61. John Carnathan also left all of his property to his spouse but provided that upon her death or remarry, such property shall be equally divided amongst his brothers and sisters. John Carnathan's Will, Greene County Wills Book B, at 154-55. James H. Foster bequeathed most of his real and personal property to his wife but only one-third of his cotton crop to her. James H. Foster's Will, Greene County Wills Book B, at 271-72. He further stated that the proceeds of what may be recovered from a lawsuit against the sheriff of Sumter County shall be divided between his two nephews, his niece shall receive one thousand dollars, and the remainder of his property shall go to his brothers and sisters, and if they die, to their children per stirpes. Id. Testator Reps Edwards also provided for his nephews, stating that they were to receive the potential profits from the sale of a person. Reps Edwards' Will, Greene County Wills Book B, at 273-75. All of Edwards' personal and real property was to go to his wife. Id. Junius C. Bonnell provided for his wife only, stating that she was to keep their home, but his real property was to be sold in order to 


\section{Slave Owners' Patterns of Bequest}

It is useful to explore further the wealth of those testators who owned slaves. Among the 27 testators who owned at least one person in the first period (1831-35), it was possible to ascertain the number of slaves bequeathed in the will for 15 of them. It was unclear how many people were owned by the other 12 testators. Of those for whom we can gauge the number of slaves bequeathed, $(\mathrm{N}=7)$ owned five slaves or fewer; $(\mathrm{N}=6)$ owned between 6 and 20 slaves, and 2 owned more than twenty. (See Table 22, Patterns of Bequest of Slaves by Testators Owning Twenty or Fewer People).

Among the 59 testators in the second period (1841-45), it was possible to ascertain the number of slaves bequeathed in the will for 52 of them. It was unclear how many people were owned by the other 7 testators. Of those for whom we can gauge the number of slaves bequeathed, $42.3 \%(\mathrm{~N}=25)$ owned five slaves or fewer; $32.1 \%(\mathrm{~N}=19)$ owned between six and twenty slaves, and $13.4 \%$ (8) owned more than twenty slaves. (See Table 23, Patterns of Bequest of Slaves by Testators Owning More than Twenty People, 1831-1845).

This leads to other questions about how those who owned a substantial number of humans (more than 20) distributed their property in comparison with those who owned fewer people. There were ten testators who owned more than 20 people in the entire sample period; $60 \%(\mathrm{~N}=6)$ of them left at least part of their estate to their surviving spouse; $70 \%(\mathrm{~N}=7)$ left at least part of their estate to children; and $80 \%(\mathrm{~N}=80)$ left at least part of their estate to other close relatives. Two (20\%) also left property to other people and two provided for charities or emancipation of some or all of their slaves. Those who owned fewer than twenty-one people had a similar but more compact set of heirs. More than sixty percent $(61.4 \%, \mathrm{~N}=35)$ left at least part of their estate to their surviving widow; 78.9\% $(\mathrm{N}=45)$ left at least part of their estate to their children. But then a substantially smaller percentage of testators $(38.5 \%, \mathrm{~N}=22)$ left property to other close relatives than did those who owned more than 20 slaves. About a quarter $(24.5 \%, \mathrm{~N}=14)$ of those who owned between 1 and 20 people left at least some property to other people; and four (7\%) left property to a charity or attempted to free at least some of their slaves via will.

\section{Equitable Distribution?}

Testators with more than one child faced difficult questions about whether they would treat all their children alike or have a favored distribution. Alabama intestate law provided for equal distribution among children. In fact, more than four in five testators in the first sample period (1831-35) who had more than one child employed an equal distribution. Among the 17 men who left more than one child, $82.3 \%(\mathrm{~N}=14)$ left equal distributions to their children; only

pay his debts, with the remainder going to the wife. Junius C. Bonnell's Will, Greene County Wills Book C, at 4?. Lastly, Robert G. Hanna bequeathed his land, household belongings, onehalf of his slaves, and \$2,000 to his wife. Robert G. Hanna's Will, Greene County Wills Book $\mathrm{C}$, at [no visible page number]. The other one-half of his slaves were to go to his brother in law. Id. Other various items were left to Hanna's brother, brothers in law, sisters in law, and nephews. Id. 
$17.6 \%(\mathrm{~N}=3)$ left a favored distribution. Of the four widows who had more than one children, $75 \%(\mathrm{~N}=3)$ employed an equal distribution. Milly Warren, however, divided her land between her two children with one child getting more personal property than the other. Her other children only received proceeds arising from another parcel of land. (See Table 24, Distribution Patterns of Testators with Multiple Children, 1831-35) For example, Honorie Bayol favored his son, who received one-half of remainder and daughters, who each received one-quarter of the remainder of his estate. ${ }^{103}$

For the second period, $1841-45,88 \%$ of fifty male testators who left more than one child employed equal distribution ( $\mathrm{N}=44) ; 12 \%(\mathrm{~N}=6)$ employed an unequal distribution. Again, the female testators who had more than one child were more likely than males to use a favored distribution. In fact, of the seven female testators who left more than one child, $57.1 \%(\mathrm{~N}=4)$ employed a favored distribution. The remaining $42.9 \%(\mathrm{~N}=3)$ employed an equal distribution. ${ }^{104}$ (See Table 25, Distribution Patterns of Testators with Multiple Children, 1841-45; and Table 26, Distribution Patterns of Testators with Multiple Children, 1831-45).

Some testators went to great lengths to establish equal distribution among children. For example, Jethro Harrison's will, probated in 1844, listed the notes and book accounts that were owed him by each of his children. Harrison owned 27 people according the to the 1840 census. He forgave the children each of their debts to him, then he used his estate to make sure that they ended up with equal amounts, and divided the remainder of the estate among the children. ${ }^{105}$ Harrison's will is a reminder that children frequently received inter vivos transfers from there parents, which make it difficult to rely solely upon probate records to determine the size of transfers from parents to children. Similarly, Charles Barry took into account inter vivos transfers to his children in computing their share, as did Peyton Keith. (They wrote about these as advancements. ${ }^{106}$ Barry's will is particularly evocative, for it gives two of his daughters an interest in a piano forte. What story might be buried in that bequest has been lost to time; however, it evokes suggestions of a family's time spent together and a connection between the past and the present, as August Wilson illustrated in his 1990 play that centered around a piano owned to two siblings. One wanted to keep it for it connected her to her family; the other wanted to sell it to buy land that the family's ancestors had worked during the days of slavery. ${ }^{107}$

For some testators, the extent to which there has been an equitable distribution is

${ }^{103}$ Honorie Bayol Will, Greene County Wills Book B, at 161-62.

104 James Derden devised a majority of his property to his wife for life and the remainder of the property was devised to the testator's children in equal shares. Henry Minor directed that his property be sold and distributed as if he had died intestate.

105 Jethro Harrison Will, Greene County Will Book C, at 62.

${ }^{106}$ Charles Barry Will, Greene County Will Book C, at 93; Peyton Keith, Greene County Will Book C, at 67.

107 August Wilson, The Piano Lesson (1990); Charles Barry Will, Greene County Will Book $\mathrm{C}$, at 94 . 
difficult, if not impossible, to determine. For instance, James McCarter's will, probated in 1844, provided only $\$ 1$ each to seven of daughters and to two sons and one daughter-in-law. ${ }^{108}$

McCarter's rationale was that they had "already received their portion as much as I design them to have of my estate." McCarter also gave his wife an estate for her widowhood (which lasted until she married or died), then left the remainder to one of his other son and another tract of land to another of his daughters.

It is difficult to know precisely the reasons why some testators had preferred distributions and others were scrupulously equal in their divisions. But in some cases, the will hints at the reasons. Polly Neely's January 1840 will left her entire estate to her youngest son and noted that she could not provide much for her other children (and their issue) if she divided her estate equally among them. To those children and grandchildren she left "my best wishes for their future prosperity, believe them all to be above wants and in situations in life in which they can by frugality and care live independent of those small amount of my property which would come to their share if equally divided among them, assuring them in the most esteemed act of my life, that it is not from a want of affection to either one of them, that I have concluded to leave them no part of my property but the consideration above made known." Neely made clear, moreover, that the youngest son had earned the money. "[M]y youngest son has devoted years of his life to my support and in taking care of me, whilst the others of my children were doing for themselves." While Neely gave preference to one child, she admonished that the favored child had responsibility to take care of her unmarried daughter. She "request[ed]" her son "to maintain my daughter Sarah Samuels as long as she may live single." 109

Hamilton Brown gave some children only $\$ 1$. Charlotte Nixon similarly essentially disinherited one of her daughters, Marsa E. Beckham; she gave her five dollars "which I consider a full consideration for the filial affection and greard she entertains for me and it's my will and desire that she have nothing more of my estate." Nixon had a substantial estate to give, however; for she left her slaves and property to her daughter Maria Taylor for life, then the remainder to her daughter's issue. ${ }^{110}$

\section{Trusts}

As one might expect from the level of wealth (and thus presumably sophistication) of the testators, a significant number employed a trust. We have interpreted some wills as creating trusts even though in some instances they do not employ the word trust. For instance, Alvis Riddle-executor to manage estate until wife dies or oldest child reaches age 21 . This is in keeping with the interpretation that a will may establish a trust even through the word "trust" is

\footnotetext{
108 James McCarter's Will, Greene County Will Book C, at 76.

109 Polly Nelly Will (Probated 1841), Greene County Will Book C, at 279.

110 Hamilton Brown Will; Charlotte Nixon's Will (1845), Greene County Will Book C, at 107.
} 
not used. ${ }^{111}$ The number of trusts (either explicit or implicit) increased from $29.0 \%(\mathrm{~N}=9)$ of wills in the 1831 to 1835 period to $41.7 \%(\mathrm{~N}=33)$ in the 1841 to 1845 period.

In the first period, 1831-35, six of the 31 wills (29\%) employed explicit trusts; all six provided for support of family members; three also provided for education of family members. ${ }^{112}$ (Table 27, Purposes for Testamentary Trusts in Wills, 1831-35) In the second period, 1841-45, trusts were slightly more popular. Of the 79 wills, $33(41.7 \%)$ employed trusts. More than three-fourths $(78.7 \%, \mathrm{~N}=26)$ provided for support of family members; more than one-third $(36.3 \%, \mathrm{~N}=12)$ provided for education of family members. Two also provided for emancipation. (Table 28, Purposes for Testamentary Trusts, 1841-45).

A simple, explicit trust arrangement was made by Elizabeth Herndon's will probated in 1833 placed some of her property in trust to her son Thomas for the benefit of son Edward, then on Edward's death, distributed Edward's share to his issue. Similarly, she put other property in trust to her son Thomas for the benefit of her three daughters. ${ }^{113}$

Other more complex arrangements began to appear in the later period. Abner Steele's will, probated in 1842, has a particularly religious opening:

I give and bequeath my soul to Almighty God, with full confidence that for the sake of Jesus Christ, his son, my saviour and redeemer, he will accept it, and keep it with him in glory forever. My body I commend to the earth there to be laid in Christian burial to remain until the trumpet of the archangel shall summon the dead to rise, and to receive sentence according to the deeds done in the flesh. My worldly goods, with which it has

111 Alvis Riddle, Greene County Will Book B, at 293; Blaney Brand, Greene County Will Book B, at 301; R. Franklin Witherspoon, Greene County Will Book B, at 278.

In these cases, there is some evidence that the will set up an executor or beneficiary as a trustee who was charged with making on-going payments to beneficiaries. Take the case of John McKee, a former member of Congress, who had been in the southeast since the late eighteenth century, as a representative of the federal government, working on Indian relations. McKee's will, probated in 1832, gave all his property to William P. Gould. Greene County Will Book B, at 88. Gould is reported as a kinsman in William Smith's Reminiscences of a Long Life 88-90 (1889). But maybe the relationship was more of a working one, for others report that William Proctor Gould was a native of Salem, Massachusetts and a secretary-aide to McKee. Gould was to make quarterly payments to McKee's son (Alexander McKee), who is believed to have been born to a Native American women. See John McKee, 6 Dictionary of American Biography 82-83 (1959). This odd legal relationship seems to establish Gould as a trustee for Alexander McKee and it hints at the possibility of a secret trust, although, obviously from the nature of secret trusts, it is not possible to determine from the will whether there is a secret trust or not. For more on Gould, see the mimeographed Diary of William Proctor Gould of Boligee, Greene County, Alabama, 1828-1864 (1938).

112 For another example of a trust for education, see Amis v. Amis, 29 N.C. 219, 7 Ired. 219 (1847).

113 Elizabeth Herndon's Will (1833), Greene County Will Book B at 119. 
pleased God to bless me I dispose of as follows.... ${ }^{114}$

Steele was born in South Carolina around November 4, 1768 and was one of the first white settlers of Greene County, in the 1810s. He left the plantation where he lived to his wife Elizabeth for life; the remainder went to his son John Steele, but if John predeceased his mother Elizabeth and left surviving issue, the issue and John's wife would share the plantation. Otherwise, the plantation would become part of the residuary. He also left a plantation in Mississippi in trust for his daughter for her life and it was to be distributed to her issue upon her death. ${ }^{15}$ Steele's carefully drafted will made extensive efforts to make sure that he children received equal bequests, including taking some inter vivos transfers recorded in a separate document into account and also taking effort to have the issue of Steele's deceased children take by representation. ${ }^{116}$

114 Greene County Wills Book C, at 2.

115

Greene County Wills Book C, at 2:

I give devise and bequeath to my sons Elihu R Steele \& R G Steele and the survivor of them \& his heirs two half quarter sections of land lying in Kemper County in the state of Mississippi, to wit, the west half of the North East quarter of section thirty five, and the West half of the southwest quarter of section twenty six all in township twelve and Range eighteen East, of the lands offered for sale at Columbus, Mississippi. Also a negro man slave named Albert, aged about nineteen years, also a negro Girl Dinah aged about ten years, also a boy named Tandy aged about six years, also a young sorrel horse called Charley, and twenty head of young cattle ranging about said lands ... to have and to hold the same, and each and every part thereof, in trust, for the use of my daughter Esther Kimbrough, for and during her life and at her death to be divided amongst her children share and share alike--the children of a deceased child to take the share, the parents would have taken if living.

${ }^{116}$ Greene County Wills Book C, at 2:

In order to equalize all, except Esther Kimbrough [who was the beneficiary of a trust], I direct my executors to appoint not less than three nor more than five disinterested respectable gentlemen who shall assess and value the property bequeathed under the will except that given in trust ... for the use of my daughter Esther Kimbrough, and what I may have advanced to any of my children for which a receipt was taken, ... and then each of my children (and the children of a deceased child, is herein called a child and are entitled to the share their parents would take if living) shall be made equal - where one has received more property than his or her share, he or she shall pay pack (back) and when one lacks his or her share shall be made up out of the residue of my estate and will be paid by those who have received more than their share. They who shall receive under this clause and be equalized are the children of my son Alexander, the children of my daughter Polly Archibald each set one share. Elihu R. Steele, R. G. Steele, Nancy 
The desire to keep property within families appears in a unique way in Absalom Morton's will, probated in 1845. Morton put his property in Greensboro in trust for his sister, Mary Taylor (who married Caleb W. Taylor on May 6, 1840) "for the sole use, benefit, and profit" of Mary and "and the issue of her body." Later, the trustee was ordered to sell the land and use the proceeds to purchased women "which said negroes with their increase when so purchased I hereby give and bequest to my said sister and the issue of her body it being my intention that my said sister and her children shall have the sole objects of my benevolence." 117 $\mathrm{He}$ also placed a slave in to provide an education for his relative, which is further evidence of the close connections between education and slavery. ${ }^{118}$ Such provisions are important for two reasons. First, they illustrates the desire to invest in human beings rather than land and the sophisticated economic ideas that antebellum southerners employed; ${ }^{119}$ second, they are clear in making the sister and her issue the beneficiaries of Morton's trust and excluding the sister's husband. ${ }^{120}$

Some of those who employed testamentary trusts employed sophisticated techniques. For example, they restricted the power of creditors and husbands from reaching the trust assets. In a few cases, they gave beneficiaries power of appointment. ${ }^{121}$ Others provided detailed

Gillaspie wife of James Gillaspie, Betsey Patton wife of William Patton, William Steele, the children of my son Abner Steele, Jane Baskin wife of Pringle Baskin, and my son James Steele. My daughter Esther Kimbrough is not included in this assessment.... Steele also asked that his slaves not be sold, if they could be divided among his heirs.

${ }^{117}$ Greene County Wills Book C, at 101.

${ }^{118} I d$. Morton provided:

I hereby give and bequeth to my cousin Absalom Alston ... my negro man David and all my books. But it is my will that the above named Duncan Alston shall have the control and management of said negro David for the benefit of said Absalom Alston until he the said Absalom shall arrive at the age of twenty one years, applying the profits of the said negro David to the maintenance and education of the said Absalom Alston.

119 Morton's will, like others that left personal property like stock, illustrate the vigorous spirit of enterprise (to borrow Thomas Doerflinger's phrase from the Revolutionary era, $A$ Vigorous Spirit of Enterprise (1986)) and progress that captivated southerners, like all Americans, in the antebellum era. See Peter Carmichael, The Last Generation (2005) (labeling antebellum southerners as "progressives all").

${ }^{120}$ Blaney Brand's will, probated in 1842, provided that his executor was to buy slaves ("they to be such as will bring in hire and be more profitable to my heirs"). Those slaves were to be hired out to "such men as can be relied on to treat them well and take good care of them." The proceeds paid to his widow and children. Greene County Wills Book B, at 301.

${ }^{121}$ See Will of Mary Cashaden, Greene County Wills Book B, at 295 ("[A]fter the death of the said Eliza J. Robinson, the said trustees shall dispose of the property thus acquired with the 
instructions to trustees regarding the education or support of beneficiaries. Some trusts provided for support for several children and even grandchildren and had extensive provisions for the termination of trusts upon beneficiaries reaching the age of majority or upon the death of one of the beneficiaries.

Mary Cashaden provided an extensive will and trust. She gave away several pieces of property spread across the south from Mobile, to St. Stephens, to North Carolina, to Demopolis to two friends, George Gaines and Thomas McKee, as well as a substantial amount of property-some of which she specified as property inherited from her husband George (and presumably other parts came from some other source, perhaps her inherited from her family) ${ }^{122}$ in trust for her daughter, Eliza Jane Cashaden. Eliza had Franklin Robinson in 1825; Franklin was a cotton merchant in Mobile in the late 1820s and 1830s. ${ }^{123}$ Cashaden took care to establish a trust that would not be attachable by Franklin's creditors, nor used by Franklin or any future husband. ${ }^{124}$ Cashaden also put other property in trust for her granddaughter, Mary Robinson. Upon Eliza's death, if Mary were of age of majority, she would get her share outright. Otherwise, the trust would continue until she reached age of majority. Conversely, if Mary had died, her property would go to Eliza's other surviving children. Cashaden concluded that her "negro woman Betsy shall not be sold at any time but that she shall be kept in the family of my

income, rents, and interest, in such manner and to such persons as she, the said Eliza shall have directed by any writing signed by her for that purpose in the nature of a last will.").

${ }^{122}$ On Gaines, see James P. Pate The Reminiscences of George Strother Gaines, 1805-1843: Pioneer and Statesman of Early Alabama and Mississippi (1998).

123 Mary and George Cashaden were from North Carolina and apparently Mary and her daughter Eliza migrated to Greene County after George died, around 1820.

${ }^{124}$ Mary Cashaden Will, Greene County Will Book B, at 295. The will gave explicit instructions to the trustees:

To have and to hold all the said property both real and personal ... upon the following uses, trusts, and confidence and upon no other use, trust, and confidence whatsoever, to wit: that the said trustees George S. Gaines and Thomas McKee shall hold all the said property, and also in the event of a sale of any part thereof, the property that may be acquired with the proceeds of such sale, in trust for the sole and separate use fo my daughter Eliza Jane Robinson, the wife of Franklin Robinson of Mobile during the natural life of my said daughter, the said property ... to be free from the control and dominion of her said husband, and not subject to any liability for his debts and engagements and in the event of the said Eliza Jane surviving the said Franklin Robinson the trustees to continue to hold all the property and not liable for the debt and engagements of any future husbands.

Eliza had the right to receive the proceeds from the trust and to occupy any of the property held in trust. 
daughter, and that upon the death of my daughter my trustees shall have her kindly taken care of and that she shall remain with my grandchildren." She also requested that her daughter "take care of my old negro men Aaron and Sam and provide for their comfortable maitenance." 125

Take Thomas Herndon as an example. Herndon had served as secretary of state in Kentucky and then as a judge in Mississippi before settling in Greene County. His son, educated at the University of Alabama and Harvard Law School, served in the United States House of Representatives after the Civil War. ${ }^{126}$ The 1840 census recorded that he owned 115 people in Greene County. Herndon, one suspects, had access to the most sophisticated knowledge of trusts then available and he provided extensive instructions to the trustee. Moreover, he tried to make sure that the trust corpus was protected against spendthrift habits of his children and their spouses. As the preamble to his will recites, he made the wills when he was "sick of body and duly apprehensive of the uncertainty of human life and anxious to make such disposition of my real and personal estate as to me seems most conducive to the future welfare of my family after my death." 127 Herndon placed his extensive plantations into trust with his executors and directed that they not be sold and that the enslaved people working on them also be maintained together on those plantations until his youngest child "becomes of age or marries." At that point, the Hernadon's widow, Elizabeth, had the right to select on of the plantations as residence which was hers "during her life if she remains a widow." The trustees were to give Elizabeth"sufficient number of negroes to support and labor for her, as is or may be compatible with the value of my estate and her condition in life." The remainder of estate was then divided equally among the children ("share and share alike"). If a "fair and beneficial" division of property in kind was not possible, then the property was to be sold and the proceeds divided equally.

While the property was still in trust, the trustees has power to manage the plantations, including to sell slaves who "may be of bad character, may be valueless, or may in any manner prejudice the interest of my estate." They also had the power to purchase others to "supply their places," for Herndon did not want "the number of negroes on the said farms to be diminished." Moreover, children who reached age of majority or separated from home during the course of the trust were entitled to income from the year's cotton crop.

Finally, Herndon made several provisions to make sure that the children's property would be protected. If his wife remarried or "dissent[ed]" to the will, then wanted her to receive only "that portion of my estate which she can obtain by law and none of the benefits or provisions of this will, the various promises herein made being intended in lieu and bar of her dower in my real estate and distinctive share of my personal property." 128 Moreover, he took efforts to protect his daughters against profligate husbands and his sons against their own profligacy. He instructed trustees to maintain control over the property of any daughter who was

125 Id. at 298.

126 Obituary, New York Times (March 29, 1883) (obituary of Thomas H. Herndon).

127 Thomas Herndon Will (1843), Greene County Will Book B, at 31.

${ }^{128} I d$. at 35. Later in the will he provides that if Elizabeth remarries, that she should receive a "child's part" of the estate. Id. at 36. 
"married to a husband insolvent, in debt, or to such a husband as my executors might suppose would manage the property indiscretely." To protect his sons, he instructed the trustees to maintain control over the property of any son who "should act in such manner as to render it indiscreet and improper to give them ... the absolute right and control to their ... portion of my estate." In that case, the children would have the "possession and usufructory interest but not the absolute dominion. The trustees were to make sure that such property "not be subjected to reckless and improper expenditures and extravagances." 129 Herndon had a partnership with to run a merchant firm in Erie, which had been the county seat of Greene County until 1838. Part of the estate was the capital in that firm; however, in a codicil, Herndon directed that the proceeds from the partnership be used to purchase a plantation instead. ${ }^{130}$

Trusts were also used to protect property from family members as well as creditors. Sarah Johnson's will recited that she placed her property in trust for daughters, to keep it out of reach of their husbands. ${ }^{131}$

In a paraphrase of Elizabeth Eisenstein's The Printing Press as an Agent of Change, one is tempted to write of "the trust as instrument of economic development."132 As Guy Hubbs observed in his recent study of the town of Greensboro in this period, there was an excitement for economic (and perhaps to a lesser extent moral) progress. Men arrived in the new state of Alabama in the early 1820 s and quickly harnessed human, animal, and natural resources, to make the land produce extraordinary wealth. They turned to a new technology to dig deep wells to produce water, and they used steam engines and turbines, along with enslaved humans, to conquer the land. And in 1831 the local newspaper cheered the many changes, which had brought Greene County in twenty years from a place where natives had wandered, to a place where crops were cultivated and civilization had been established. ${ }^{133}$ Henry Watson, a lawyer

129 Id. at 36.

${ }^{130} I d$. at 37 (Herdon's codicil, which instructs executors to purchase a plantation).

131 Sarah Johnson's Will (Probated 1844), Greene County Will Book C, at 84; Dabney McGehee (Probated 1843), Greene County Will Book C, at 55-57 (appointing one of testator's son trustee of property for benefit of testator's daughter and noting that daughter's husband is not to receive anything).

132 See Elizabeth Eisenstein, The Printing Press As Agent of Change (1980).

133 HubBs, supra note 71, at 28. Such expressions of progress were pronounced in the literary addresses of the time, in Alabama as well as elsewhere. See Alfred L. Brophy, "the law of descent of the mind": Law, History, and Civilization in Antebellum Literary Addresses, 20 LAw AND LiterATURE 343-402 (2008); Alfred L. Brophy, The Intersection of Slavery and Property in Southern Legal Thought: From Missouri Compromise Through Civil War chapter 1 (Ph.D. Dissertation, Harvard University, 2001) (discussing image of progress in Northern literary addresses). Of course judges invoked the idea of progress in their judicial opinions. See Alfred L. Brophy, Property and Progress: Antebellum Landscape Art and Property Law, 40 McGeorge L. Rev. 599 (2009). 
and a recent transplant from Connecticut, noted in his diary that another Connecticut Yankee transplanted to Greensboro-the physician Dr. Withers-"Goes all for money." 134 Watson went for it, too. He was soon operating a bank and an insurance company and owned 900 acres by the middle of the 1840s. Besides the technological innovations-like the means of drilling wells hundreds of feet deep, and the stream engine-Greene County residents employed a rapidly changing legal device: the trust. John Langbein has already shown that the trust shifted in the nineteenth century from a device for managing real estate to a much more flexible device for managing personal property and businesses. Langbein dates the emergence of the trust as an agent of economic and personal property, rather than land management, later in the nineteenth century. ${ }^{135}$ But it should not surprise us; in fact, we should expect, that the boom times of the early 1830s in the frontier-what Alexander Baldwin referred to in his novel as Flush Times in Alabama and Mississippi-would so rapidly search out innovation and embrace it.

\section{Challenging the Will and the Probate System}

In some cases, testators anticipated some conflict in the administration of estates, so they provided (as in the will of Gabriel Long) for the arbitration of disputes. Long requested that if any disputes arose in the division of his estate that "the contending parties should each chose a man and they to chose a third person to settle the difficult and their decision to be as valid as if settled by the Supreme Court of the land." 136

At least four of the cases studied here led to lawsuits. One was a challenge to Rachel Wedgworth's will probated in 1844. ${ }^{137}$ The basis for the challenge (whether the will was "a valid will according to the evidence") is not preserved in the scant records available on the case. However, it may have something to do with Wedgworth's statement that she owned no property beyond what she was entitled to as James Wedgworth's widow. She then gave bequests of \$200 to several children and grandchildren and provided that eighteent months after her death, two two men, Stephen Wedgworth and Thomas Edmiston-a son and son-in-law of James Wedgworth-should loan out the land that remained in her estate and use the income to pay ongoing annuities to several of Wedgworth's female children. Upon the death of one of the beneficiaries, the land was to be sold and divided on an equal basis between the beneficiaries. Stephen Wedgwoth and Thomas Edmiston were entitled to whatever else remained. They challenged the will; the defendants were the beneficiaries under the will. Whatever the basis for

134 HubBs, supra note 71, at 15. On Watson's education at Trinity College in Hartford, Connecticut, then his attempt to establish a school in Greensboro, and later reading of law back in Hartford and return to Greensboro in 1833, see Myra M. Sampson, A History of the Watson Family of Northampton [Massachusetts] (1968).

\footnotetext{
135 John Langbein, The Secret Life of the Trust: The Trust as an Instrument of Commerce, 107 YALE L. J. 165 (1997).

136 Gabrial Long's Will, Greene County Will Book C, at 39, 40.

137 Rachel Wedgworth's Will (1844), Greene County Will Book C, at 83.
} 
challenge, the jury found it insufficient and upheld the will.

Three other lawsuits around from the wills probated in this study; each of them revolved around the probate of the estate, rather than the testator's capacity. The first case, Scott v. Nelson, ${ }^{138}$ involved the testator William Bell. Bell's brief will, probated in 1834, provided for a life estate in his real property for his widow and then on her death an equal division among his children. Moreover, he bequeathed his widow some personal property, including several human beings, and the remainder of his personal property went in equal portions to his children. But one of his children had already died and the question became whether that child's son (Bell's grandson) should take in place of his father. Bell was explicit that he wanted an equal division of the property between his children and he included certain advancements already given to the children in his will-including an advancement to the son who had died by the time of the making of the will. Thus, it appeared that Bell contemplated the predeaceased son's estate taking a share. Chief Justice Henry Hitchcock, a native of Vermont (and grandson of Revolutionary War hero Ethan Allen), concluded that the grandchild should take by representation. It illustrates a flexible jurisprudence of wills, from a time when the court was willing to construe a brief will in a manner to effect testator's fairly obvious intent. ${ }^{139}$ Hitchfock was the author of the first book published in Alabama-unsurprisingly a lawbook, Alabama Justice. ${ }^{140}$ Perhaps Hitchcock, who was born in 1792, illustrates an Enlightenment jurisprudence, before the descent of the formalism for which law in the nineteenth century is notorious.

The second case Meador v. Sorsby, ${ }^{141}$ involved testator, James Meador. It limited the power of executors to sell property acquired by the testator after execution of the will. The final case arising from wills studied here Childress v. Bennett ${ }^{142}$ involved testator William Bennett, whose will provided a life estate for his wife and then an equal distribution between Bennett's nine children. If Bennett's widow remarried, she was to lose her life estate. ${ }^{143}$ Bennett estate

1383 Port. 452 (1836).

${ }^{139}$ Greene County Will Book A, at 153.

${ }^{140}$ Henry Hitchcock, Alabama Justice (1822). See also Herbert J. Lewis, A Connecticut Yankee in Early Alabama: Henry Wilbourne Stevens and the Founding of Ordered Society, 1814-1823, 59 Ala. Rev. 83-106 (2006). See also Daniel J. Hulsebosch, An Empire of Law: Chancellor Kent and the Revolution in Books in the Early Republic, 60 Alabama Law Review 377-424 (2009) (discussing the presence of law books in early Alabama).

1412 Ala. $712(1841)$.

14210 Ala. 751 (1846).

143 William Bennett Will (1843), Greene County Will Book, at 58 ("I wish it distinctly understood that should my wife marry at any time that she is to be debarred of any of my property, but I with the property to be kept together until the youngest child becomes of age. But should she not marry she is to be entitled ot a support during her lifetime. It is to be understood when the youngest child becomes of age that the property shall be divided equally, among my above named nine sons except so much as will be a sufficient support for my wife 
sought ancillary probate in Greene County (he was domiciled in Tennessee at the time of his death). And his debts in Tennessee exceeded his assets; however, his assets in Alabama exceeded his debts, so the Alabama Supreme Court faced the question whether the Greene County Orphan's Court could order that Bennett's Alabama property be paid to his executor so that the executor could use it to satisfy the Tennessee creditors. The Alabama Supreme Court concluded that the Greene County court had the power to order the payment of Bennett's property to Tennessee for the satisfaction of his creditors there.

Another suit arising from probate in Greene County involved the testator George Hays, whose will was probated in 1838. Hays was a wealthy man; he owned approximately 180 people and three plantations spread across Alabama and Mississippi. He died between the years studied here, so his will did not appear in our data set. However, the lawsuit, Hays v. Leachman, has recently received substantial attention in Loren Schweninger's The Southern Debate over Slavery. Schweninger begins his book with the suits by Hays' heirs regarding, first, Hays' estate, and then the mistreatment of slaves by Hays' widow. The records of the case preserve vivid portraits of the violence that lay at the heart of the institution of slavery. The lawsuit gives us a picture of how the human dimension of the slave system was resolved into a ledger, which recorded the losses to Hays' heirs (his children, including his son Charles Hays who served in Congress in the years following the war, and Hays' widow) because of the brutality of those hired to run the plantation by his executors. ${ }^{144}$ The first suit was filed by Hays' widow, who remarried within a year of his death, to obtain her dower portion (rather than the annuity of $\$ 1500$ per year she would receive under his will). Then the widow, after winning a one-third interest, hired brutal overseers to run the plantation. ${ }^{145}$ The allegations of abuse are extraordinary, including the death of a slave at the hands of an overseer. The suit reminds us that the probate process was an on-going concern, which involved not just the collection of debts, liquidation of assets, and payment of money. It also involved the running of plantations for an extended period of time. In slaveholding regions, the death of a slaveholder often

during her life, provided she does not marry and should she have any thing remaining at her death it is to be equally divided among the said nine sons.").

144 See William Rogers, Black Belt Scalawag: Charles Hays and the Southern Republicans in the ERA of ReCONSTRUCTION (1993).

145 William Proctor Gould, who was discussed earlier, supra, served as executor of Hays' estate. On Gould, see Charles S. Davis, The Cotton Kingdom in Alabama 39, 41, 48 (1939). Gould's "Rules and Regulations for the Management of Slaves," in the Hill and Howth Plantation Records, at the Alabama Department of History and Archives, has received a small amount of attention. See, e.g., Kenneth M. Stampp, The Peculiar Institution: Slavery in the Antebellum South 431 (1956). Gould's Civil War diary, which has his thoughts on the summary execution of 17 slaves in Sumpter County, is discussed in David Grimsted, American Mobbing: 1828-1861-- Towards Civil War 173 (1998). 
involved substantial numbers of humans, beyond the slaveholder's immediate family. ${ }^{146}$

\section{E. Slaves Freed and Distributed}

Although the vast majority of Greene County testators bequeathed their slaves to their spouses or other close family members, a few attempted to emancipate their slaves through charity, trust, or the four corners of the will itself. No testator among the 1831-1835 group attempted emancipation, but $8.5 \%(\mathrm{~N}=5)^{147}$ of the $1841-1845$ slaveowning testators ${ }^{148}$ provided for emancipation in some fashion.

\section{Testators Who Emancipated Slaves In Green County}

Testator Thomas Sydenham Witherspoon conveyed twenty-five of his slaves to the president of the American Colonization Society at the time of his death. ${ }^{149}$ Such disposition was the only one in this study which could be classified as both a charitable donation and an emancipation provision. Witherspoon was born in 1805 in South Carolina, then moved with his family in the early 1820 s to Greensboro. He graduated from Union College in New York in 1828 , then returned to Greensboro, where he studied for the Presbyterian ministry. He ministered in Greensboro for fifteen years and was preparing to occupy a chair in theology at Georgia's Oglethorpe College, when he died. In addition to his will, we know about Witherspoon's bequest because Witherspoon's executor, Robert McFadden, corresponded with Henry Clay (the president of the American Colonization Society) about how to proceed. The executor suggested that the Society employ Eutaw lawyer Charles Innes Thornton to insure that

1462 Loren Schweninger, The Southern Debate Over Slavery: Petitions to Southern COUnTy COURTs 1, 34, 279 (2008) (discussing litigation regarding executor's management of estate of Hays, who died in 1838).

147 The category, "Charity and/or Freed Slaves," appears in both Table 20, "Objects of Bounty of Unmarried and Widowed Testators, 1841-1845," and Table 11,"Objects of Bounty of Married Testators, 1841-1845." Adding the data together in the two charity/slave categories results in a total of six testators who made bequests to charity and/or freed their slaves in the $1841-1845$ period. Five out of those six provided for emancipation. The remaining testator, Rebecca Bell, only satisfied the charity prong by making a $\$ 25$ donation to the American Bible Society. Will of Rebecca Bell, Book C, 46 (1843).

148 Table 5, "Testators Who Owned People, 1841-1845," indicates that there were 59 slave owners in this period, as measured devises regarding human property in their will. It is possible that some of those owned no one and that other slaveowners were did not mention slaves in their will.

Will of Thomas Witherspoon, Book C, 108, 109 (1845). 
the slaves were freed. ${ }^{150}$

Other testators generally provided freedom for their slaves, but details regarding what would become of these freedmen were not commonplace. For example, testator James C. Locke provided for the emancipation of three slaves, stating that he gave the slaves, "Nancy and her children Elizabeth and Duncan to my brothers John and William Locke to be kept and disposed of by them according to a request made by my sister Margaret [,] which is that they shall be set free if the same can be done according to the laws of this state." ${ }^{151}$ The absence of an economic support plan for such slaves, as well as the attenuated chain - that two brothers must carry out the wishes of one who is not even the testator if the law allows - made it unlikely that these persons, and others similarly situated, would experience liberty until the end of slavery in 1865. However, that might be a trust for quasi-liberty, which was looked upon with skepticism by the courts at the time.

There is something else of interest about Locke's devise, however. He freed three slaves because of a request of his sister, which illustrates one way that anti-slavery women might have an effect. It is an early version of Little Eva's request in Uncle Tom's Cabin that Uncle Tom be freed. Yet, Locke also he left a number of other human beings to his two brothers, and he named the people and their family relationships in stating who would go to which brother.

Another testator, James H. Foster, also created a contingent emancipation plan. Foster provided for the emancipation of all slaves who reached the age of fifty years if the "law of the land" permitted freedom. ${ }^{152}$ It is plausible that the age condition was employed relative to the working ability of such slaves. However, Foster appeared to be more serious about emancipation than Locke, for he added a disinheritance provision. Anyone "objecting to this [provision] shall receive nothing under this will." 153

There were two notable exceptions to the previous general emancipation provisions. First came John Pickens. He was a skeptical testator, as evidenced by his opening statement that denigrated the probate system for failing to carry out the intentions of testators. ${ }^{154}$ Nevertheless, Pickens wished that his brother free two slaves, but also established an "annuity" for the support of these slaves after they were freed. ${ }^{155}$ Pickens intended for the annuity to support a certain

${ }^{150}$ Letter of Robert H. McFadden to Henry Clay (Jan. 19, 1846), in 10 The PAPERs Of Henry Clay: Candidate, Compromiser, Elder Statesman January 1, 1844-June 29, 1852 253-54 (Melba Porter et alia eds. 1991); 4 Owen, supra note 80, at 1795; William B. Sprague, Annals of the American Pulpit ... 758-59 (New York, Robert Carter \& Brothers, 1858).

151

152

153

154 Will of John Pickens, Book C, 72, 73 (1844) ("I am aware that after the death of an individual that his wishes while living are disregarded and often not carried out after his death, this I think highly criminal, in the present case I feel no doubt.”).

Will of James C. Locke, Book C, 85, 86 (1845).

Will of James H. Foster, Book B, 271, 271 (1841).

Id.

Id. 
female slave, Caroline, as well as her child, Sarah Ann, and Caroline's future increase for the duration of these persons' lives. ${ }^{156}$ Pickens directed his brother to distribute the payment of $\$ 300$ every year and appointed his brother the guardian of Sarah Ann. ${ }^{157}$ The will of James Jones was unique. Jones is the only testator who created a trust for the sole purpose of freeing his slaves. ${ }^{158}$ Jones stated that such persons were to be held in trust so they could "be sent to some place where slavery does not exist [and] where they can be free."159 Jones further supplemented this wish with the suggestion that "the British West India Islands would be the suitable place, or Liberia." "160 Yet, for some reason the slaves seem not to have been freed. A James Jones, Junior is listed in the 1860 census in Pine Ridge as the owner of 100 slaves.

The vast majority of people were held in slavery, however. In some instances testators gave instructions to hold slaves together, if possible. At other instances, they explicitly authorized the sale of slaves. Thomas Herndon's will, probated in 1843, for instance, authorized executors to sell slaves of "bad character." Yet others gave detailed instructions on the division of their enslaved property. Such wills provided what one might refer to as "slave distribution charts." One such detailed instruction was provided by Gabriel Long's will probated in 1843; another is Charles Kennon's will probated in 1843 . Social historians are increasingly mining wills as a source of understanding of slave families or for reading slaveholders' attitudes towards individual enslaved people. One may profitably speculate on the meaning of bequests of particular slaves to their surviving spouse or their children, ${ }^{161}$ though such social history purposes are beyond the scope of this article.

\section{Vignettes of the Testators who Emancipated Slaves in Marengo County}

After the decease of my wife ... I desire my slaves to be liberated if they prefer it by placing them at the disposal of the American Colonization Society and they are to be furnished with such an amount of money as may be sufficient to support them the first year in Liberia ...

James M. Davenport, Marengo County Testator, $1842^{162}$

A similar picture of limited emancipation arises from Marengo County, another of
156 Id.
157 Id.
158 Will of James Jones, Book C, 89, 90 (1845).
159 Id.
160 Id.
161 For instance, James McCarter left particular slaves to his daughter. See Will of James McCarter, Book C, 76 (probated 1844).
162 Will of James Davenport, Marengo County Probate Records (1842). 
Alabama's affluent black belt counties. Of the large number of Marengo County testators who devised slaves throughout the antebellum period, some provided for emancipation. One testator left his human property to the American Colonization Society. ${ }^{163}$ Another testator, Asa Bishop, provided that a particular slave "be learnt [sic] to read in the New Testament."164

Of wills sampled in Marengo County in 1838-1845 in a smaller study that tested the viability of the empirical study of Greene County probate records, 9.1 percent of testators $(\mathrm{N}=44)$ established conditions or procedures for the manumission of at least one slave. Polly Glover provided that her slave, Armistead, was to remain under the guardianship of her son "until his freedom can be procured." If Armistead could not be freed, he was to go to the testator's grandchildren. Asa Bishop, in addition to the religious instruction, desired that his slave be taught "the [b]lacksmith["]s trade or the art of making wagons ... until he arrives at the age of twenty-two," which Bishop designated as his emancipation year. Lastly, James Davenport - the testator who left his human property to American Colonization Society - gave his slaves the opportunity to choose freedom or to choose their next master. If the slaves chose to remain in servitude, a portion of the proceeds from their sale would serve as a charitable devise. We wonder if the slaves were given to the Episcopal Church in Demopolis, because Davenport is known as its founder.

Most courts, however, routinely held that such freedom provisions were unenforceable. Many states even had statutes that prohibited emancipation through a will. Several Alabama decisions prove instructive. In Carroll v. Brumby, ${ }^{165}$ the Alabama Supreme Court held that the slaves that were conveyed had no legal capacity to choose their freedom, despite the fact that the testator explicitly granted them the authority to make this decision. Likewise, a slave could not bring an action for his freedom or funds and property conveyed to him via will. ${ }^{166}$ The case of Alston v. Coleman, ${ }^{167}$ however, is of particular relevance to this study because it pertains to the will of Jesse Coleman, one of the Marengo County testators sampled here. Coleman devised an enslaved child to his wife for her life, and directed that the slave be emancipated at his wife's death. ${ }^{168}$ Coleman stated that his executors were to retain $\$ 1,500$ from a sale of property and apply it to the slave's needs. Coleman also made a similar bequest to his son, providing that such slave should be set free after twenty years. The probate judge in Marengo County held that the $\$ 1,500$ conveyance for the slave's benefit was illegal and directed it into the residuary. The Alabama Supreme Court, however, focused on the emancipation terms, which it found illegal. The court also held that the $\$ 1,500$ bequest was void, reasoning that any "bequest of goods and

\footnotetext{
163 Amos J. Beyan, The American Colonization Society and the Creation of the Liberian State: A Historical Perspective 1 (1991).
}

164 Will of Asa Bishop, Marengo County Probate Records (1841).

16513 Ala. 102 (Ala. 1848).

166 See Hooper v. Hooper, 32 Ala. 669, 4 (Ala. 1858).

1677 Ala. 795 (Ala. 1845).

168 Alston, 7 Ala. at 1; Will of Jesse Coleman, Marengo County Probate Records (1839). 
chattels" for a slave's benefit is prohibited by law. Coleman's attempted emancipation was a failure, as was easily predictable given the state of Alabama statute and case law by the 1840s.

\section{Distribution of Slaves in Greene County, 1831-1845}

Along these lines, perhaps the strangest provision in any of the 110 wills under study here is John Pickens' provision that a slave child, Alfred, who had warmed his feet during Pickens' illness-and who subsequently died, would be buried with him. Pickens described the relationship in this odd way:

Having lost my much devoted little boy Alfred, who I do think possessed the finest disposition of any child I ever knew, and being ardently attached to him, I do hereby desire that his remains by taken up and deposited at my feet whenever I may be buried. This request may seem singular, but really if I though tit would be neglected I would die miserable. I will remark that for years of my illness I was much troubled with cold feet in the winter and the application of hot bricks answered only as temporary relief, this little fellow remarked that if I would let him sleep at my feet that he would keep theme warm, which I consented to and derived much comfort form the experiment. I therefore desire that when I am laid in my last bed that he may occupy the same position that he was allowed to do when we were living. ${ }^{169}$

Pickens' will was, in fact, unusually expressive. He realized that "after the death of an individual that his wishes while living are disregarded and often not carried out after his death." He found this "highly criminal." Pickens left all his property to his brother with the exception of several slaves whom he wanted freed and paid annuities.

Harris Tinker, who owned 148 slaves according to the 1840 census, was likely the most affluent testator in this study. His will, like Thomas Herndon, employed a sophisticated trust. Tinker wrote his will while at Hot Springs, Virginia where he was "dangerously ill ... but of sound mind and memory." "170 Tinker instructed his executors to continue the operation of his plantations "by working my slaves on them as they have been managed heretofore by myself."

169 John Pickens' Will, Greene County Will Book C, at 72. Pickens, for instance, began his will be noting that he could not find his previous will and because he thought that he might have destroyed it by mistake and he realized that he might die at any moment, he wrote another one: "Where the uncertainty of this life is such that I deem it necessary to arrange my worldly affairs that should I die at any time my property may be disposed of as I desire, I have made heretofore a memorandum [of my?] will which I have searched for to day, but cannot [find it.?] I think it possible that I may have destroyed [it. I?] have therefore thought fit to this my last [will. I revoke?] all others..."

${ }^{170}$ Harris Tinker's Will, Greene County Will Book C, at 78. That Tinker was vacationing at Hot Springs is itself a story of increasing affluence and modernization. See Rebecca Cawood McIntyre, Promoting the South: Tourism and Southern Identity, 1840--1920 (Ph.D. dissertation, University of Alabama, 2004). 
The proceeds were to be used first for the support of his widow and minor children, then to purchase another 240 acres adjacent to his land in Greene County, then to provide an outright gift of $\$ 20,000$ to his son Robert Tinker. He also provided for similarly large outright gifts-of $\$ 20,000-$ to each of his children upon reaching age 21. In addition, 700 acres of land was given outright to his son Harris Tinker. When the youngest child reached age 21, the residue of the estate was divided between all the children (other than his oldest son), "share and share alike." The daughters' share, however, was to be held in trust by Robert Tinker "for the sole, separate and exclusive use of my ... daughters respectively during their natural lives, free from all liability to their husbands debts or controls, and after their respective deaths convey the shares of each equally to her children and grandchildren, such grandchildren however to be the children of a deceased child and to take only such share as their parents would have been entitled to, had he or she been living." ${ }^{\prime 171}$ If Tinker's wife remarried, she would receive $\$ 10,000$ in lieu of any other rights under the will. ${ }^{172}$

\section{Conclusions}

There are two other key questions that could not be answered by our methodology. First, how much did Greene County residents transfer property during life (and to the extent that Greene County residents use inter vivos transfers, how did they compare with their probate transfers in terms of people receiving property). Second, how did heirs react to the wills? We have discussed three lawsuits that made it to the Alabama Supreme Court from Greene County. However, it remains for further research to look for other will challenges. ${ }^{173}$ Those three cases fit with wills research that suggests that bequests that are unusual are more likely to be challenged. In the case of Hay's 1838 will, the complexities of administration of the estate led to further conflict between the executor and the testators' heirs (his children).

It is, of course, difficult to tease out the meanings of these legal documents for what goes on inside the heads of their authors. As their contemporaries pointed out, people reacted often to a set of simple stimuli-ruled in part by their passions or the desire for expediency. ${ }^{174}$ Susannah

\footnotetext{
171 Id. at 80 .
}

172 Id.

173 Testator, William Bennett, Childress v. Bennett, 10 Ala. 751 (1846); Testator, James Meador, Meador v. Sorsby, 2 Ala. 712 (1841); Testator, William Bell, Scott v. Nelson, 3 Port. 452 (1836).

174 One engaging article pointed out the difficulty of understanding human motivations: A whirl of miscellaneous ideas - germs and atoms of thought, resembling those animalculae which require the powers of the telescope to bring them into distinct vision, and when there, present every imaginable heterogeneity of form, is perpetually going on within every man's brain, savage or sage, and certainly most to the disturbance of the civilized man: even many very clever persons use their minds, like their watches, without examining into their interior mechanism, following only some index on their surface, 
Blumenthal has pointed out in her work on courts' treatment of testators' intent in this period, that courts had a variety of responses to testators' (sometimes outlandish) devises. ${ }^{175}$ Those deviant wills cast light on how antebellum science understood the working of the mind; they distinguished between eccentricities, moral unsoundness, and depravity. But the wills studied here-and the vast majority of wills in the antebellum era, one suspects-illustrate more commonplace concerns. They revolve around issues of protection of dependents, sometimes of preservation of dependants against unscrupulous others (husbands and creditors) and from the dependants' own poor judgment, as well as preservation of wealth within the family.

Our findings suggest that the probate process was a vibrant institution, employed by many, to maintain property within the family. In some cases it employed the flexibility and sophistication of trusts to accomplish even more precise and sophisticated goals. ${ }^{176}$ For those

according as the springs of passion, fashion, or expediency, may direct. Half Hours, The Metropolitan Magazine 312, 313 (1838).

175 Susanna L. Blumenthal, The Deviance of the Will: Policing the Bounds of Testamentary Freedom in Nineteenth-century America, 119 HARV. L. REV. 959 (2006).

176 Among the questions one might want to address are whether legal innovation in women's property right, such as increasing power of married women, lead to more outright bequests, rather than them staying as trust beneficiaries? For example, in 1848-a period just after that studied here, the Tennessee Supreme Court addressed women's increasing autonomy with property. At first the common law neglected the property rights of married women:

The common law, which, in its origin, was of rude and harsh bearing upon the relations of life, and formed from the manners and customs of a stern and haughty people, held the rights of married women in no regard in relation to personal estate or to contracts entered into during coverture. They, therefore, could possess no personal property independently of their husbands, and make no contract in relation to any subject whatever which would be held obligatory for or against them.

Powell v. Powell, 28 Tenn. $477 * 1-2$ (1848). Later, however, married women's property rights increased:

But the advancement of civilization and the increase of commerce, which have always gone hand in hand, being productive of their usual results in harmonizing and softening social relations, and in increasing the amount and value of personal property, the rule which prohibited married women, constituting so important a branch of the human family everywhere, from becoming the owners thereof in their own right, and making contracts in relation thereto, was felt to be an evidence of barbarism, and the courts of England at a pretty early period, especially in chancery, began by one device and another to introduce into the administration of justice, in relation to this subject, principles from the civil law more in consonance to justice and humanity than had been before applied. This was at first done with a trembling hand, but, growing bolder by practice and precedent, a wide range was assumed, and principles laid down and established for the protection of married women in the enjoyment of their private estate, personal as well as real, upon a broad basis .... 
affluent Alabamians living in Greene County who employed the probate process, they often passed property onto the next generation. As affluent Southerners they employed wills and trusts to perpetuate wealth within their families, how their practices differed (if at all) from the Greene County planters' northern counterparts invites further study.

All of the tables referenced here are available on the internet at: http://blurblawg.typepad.com/files/greenecountytables2-1.doc 